\title{
Laurence Alfred Mound and his contributions to our knowledge of the Thysanoptera
}

\author{
JOE FUNDERBURK ${ }^{1} \&$ MARK HODDLE ${ }^{2}$ \\ ${ }^{1}$ Department of Entomology and Nematology, University of Florida, Quincy, Florida, 32351 USA \\ E-mail: jef@ufl.edu \\ ${ }^{2}$ Department of Entomology, University of California, Riverside, California 92521 USA \\ E-mail:mhoddle@ucr.edu
}

\begin{abstract}
Laurence Alfred Mound became interested in taxonomy after two postgraduate periods at the British Museum of Natural History (now the Natural History Museum) in London where he discovered biological diversity and the endless variety of living things. While working in Nigeria and the Sudan, and studying variation in whitefly populations, he gained an appreciation for the great differences within species in behavior and morphology under varying environmental conditions. He was appointed to the British Museum of Natural History in 1964 where he worked on the taxonomy of thrips, whiteflies, and aphids until he retired as Keeper of Entomology in 1992. He now lives in Canberra, Australia, serving as an Honorary Research Fellow, CSIRO Ecosystem Sciences at the Black Mountain Campus. Driving questions motivate him and provide insight into his thinking of the natural world: Why are there so many species of insects, yet so few species of thrips? Why so many at one place but so few at another? Do environmental and host plant factors drive the astonishing levels of morphological variation seen in single species? If so why? Why do so few thrips vector plant viruses, but why are those few so successful? Why are so many thrips associated with Acacia trees in Australia but so few on other plants? To address these questions and as part of his ongoing efforts to document the biodiversity of thrips, Laurence Mound has established 90 new Thysanoptera genera, and described 641 new species of thrips. These taxonomic designations are new hypotheses inviting scrutiny and study. At the time this document was written Laurence's research articles had been cited almost 1,300 times. Here we review Laurence Mound's career to this point, and we discuss the quality and quantity of his remarkable accomplishments in taxonomy, as well as highlighting his distinctive personal characteristics.
\end{abstract}

Key words: Laurence Mound, biography, scientific contributions, Thysanoptera

The greatest discovery of modern science was of the dimensions, not of space and time, but of human ignorance.

Lewis Thomas (1913-1993), physician, poet, etymologist, essayist, administrator, educator, policy advisor, researcher

Where is the wisdom we have lost in knowledge? Where is the knowledge we have lost in information?

Thomas Stearns Eliot (1888-1965), poet, dramatist, literary critic

The difficulties in writing this biography became evident at the very beginning when trying to decide on a title. Laurence Mound cannot be labeled adequately as a taxonomist specializing on the Thysanoptera, even though his contributions encompass the worldwide fauna. His interests are eclectic, and his accomplishments range throughout the arts, science, technology, education, and administration. His contributions to taxonomy are not simply about describing species, they are essentially about understanding patterns of variation and the biological and ecological underpinnings responsible for what is observed. In addition to taxonomic and phylogenetic contributions to the Thysanoptera, Laurence has for decades contributed to our understanding of thrips behavior, life-histories, diseasevector ability, host-plant relationships, the biochemical and genetic makeup of thrips, and the propensity of a minority of species to behave as invasive pests. The Thysanoptera are included in the title because this is the group on which he has devoted most of his study. Without doubt, Laurence Mound is the doyen of this group of insects 
and his work has inspired many, including the authors, to work on thrips and to produce work of similar high standards.

A unique combination of characteristics combines to make Laurence Mound a highly unusual and transformative individual. He looks very closely, and he encourages others to look very closely. He has remarkable, almost tireless energy. His commitments to science are unwavering. As one would expect for someone with these attributes, he frequently is dismissive and always he is demanding. His expectations of colleagues encompass knowing what and how, working hard, publishing, and constantly asking why. The only way to establish a continuing scientific dialog with him is to earn his respect through informed thinking, by challenging his thinking, and by contributing. His mentoring has been a source of inspiration for the authors, and it has motivated us to a greater commitment to thrips, and to entomology and the scientific principle in general. Ultimately this inspiration has increased the quality and quantity of our research on thrips, which by extension has increased the quality and quantity of research of our colleagues and students.

Laurence Mound's thought-provoking and inspiring lectures at the opening or closing of scientific meetings and international congresses are legendary. He was the 1998 Pioneer Lecture Honoree at the meeting of the Florida Entomological Society to commemorate the achievements of Wilmon Newell, an early pioneer in Florida, leading to eradication of the Mediterranean fruit fly and numerous other invasive pests. Newell's scorched-earth approach was conducted without regard for the environment and at extreme economic loss to growers. His eradication methods highlighted one of the greatest problems associated with pest control - the view that it is actually possible to eradicate one type of organism without affecting the lives of other organisms. Laurence Mound emphasized that good integrated pest management demands that we learn all that we can about the biology of our target pests and their relationships to our crops, and that we also have a sound knowledge of the other organisms that are in and around these crops. Good integrated pest management recognizes that these different organisms are interdependent, and that disrupting one will have effects on others. Laurence was reluctant to publish his lecture in writing, even though it is traditional that the Pioneer Lectures are published in the Florida Entomologist. He pointed out that a lecture as an effective method of communication is structured very differently from written forms of communication. Eventually, a paper was published that captured the essence of the oral presentation, although the lecture was indeed more spell-binding and inspirational (Mound 2005a).

A similar effect was imparted in 1999, when Laurence Mound addressed an audience of extremely upset and uncertain avocado growers in Ventura County, California USA. The avocado industry had been ravaged for two consecutive years by the avocado thrips, Scirtothrips perseae, a species new to science at the time of its first detection in the USA. The impact this talk had cannot be underestimated - it challenged the fundamental pest and avocado tree management practices used in California, it alerted California's growers to a much wider and growing problem, that of invasive species. The talk drew beautifully upon Civil War analogies to which most, if not all, meeting attendees, either native US citizens or those well versed in history, could relate. The crowning pieces in the lesson on how to prepare for, manage, and adapt to invasive thrips of agricultural importance were modified from The Art of War by Sun Tzu. This talk riveted and inspired one of the authors (MH) who decided Laurence Mound was someone from whom he wanted to learn and with whom he wanted to work.

Laurence delivered a plenary lecture at the 2009 German Entomological Society. In this he explored the view that the descriptive sciences of taxonomy, systematics, and morphology are widely viewed as un-intellectual, and not worthy of study. He used studies on the Thysanoptera as a basis for considering the origins of, and the measure of truth for these prevailing views. His argument is that the description of a new species is a new hypothesis that is available for testing. In practice, many descriptions are published to provide a name for a specimen, and in the absence of biological data, these hypotheses go untested. In the plenary lecture, he outlined an approach that society in his view has a right to expect from descriptive biologists - the development of sufficient understanding of natural history to facilitate maintenance of ecosystems on which mankind depends. This view was developed from a talk in Piracicaba, Brazil in 1995 under the title "Is taxonomy boring — or is it just the taxonomists?" Another of his interests, effective communication, was emphasized when he gave the final plenary lecture at the International Congress of Entomology in Florence in 1996. He stressed the importance of electronic communication, not just in publishing scientific results but also in teaching students.

The lecture at the German Entomological Society focused on a single diverse lineage of Phlaeothripinae, known to feed exclusively on the foliage of Acacia species, a plant genus of around 1000 species across Australia. Mound's (1970a, 1971a) earlier systematic research on Acacia thrips — the field work conducted for twelve 
months in Australia while he was employed at the British Museum of Natural History (BMNH, now the Natural History Museum) - led to the remarkable behavioral studies by Crespi (1992a,b) and a resurgence of interest in the group. Laurence Mound has continued working with colleagues on the great diversity in structure, ecology, life history, and behavior of Australian Acacia thrips; the patterns in host-plant relationships; and the ways in which complex interdependences have driven patterns of insect diversity, behavior, and host-plant association. Over 235 thrips species associated with Acacia are named in Crespi et al. (2004) and 140 are described for the first time in this book; 58 were described by Mound and colleagues during the course of the project, prior to publication of the book. The taxonomy, including the species descriptions, are Part II of the book. Part I covered the ecology and evolution of Australian Acacia thrips. Together the authors pioneered a model clades approach for the analysis of behavior, ecology, and life-history of the Australian thrips associated with Acacia. A systematic, phylogenetic framework was developed from a robust taxonomy coupled with phylogenies at the species level and data on biogeography, behavior, ecology, life history, and other aspects of phenotype and genotype. This allowed for robust, multidisciplinary tests of hypotheses.

Laurence Mound's lectures often include constructive criticisms of his colleagues. At the international meetings of Thysanoptera and Tospoviruses, he has systematically urged researchers to look holistically at the plants, the thrips vectors, and the tospoviruses as interdependent, co-evolved organisms. He has remarked on several occasions that most virologists simply view thrips vectors as 'flying syringes.' He emphasizes that sound, ecologicallybased, integrated pest management can only be derived by understanding the complex interdependencies in the biologies of all three components. Cross discipline studies are required if sustainable and effective strategies are to be developed, implemented, and adopted by end users.

While writing this manuscript in the office of Renato Ripa in La Cruz, Chile, one of the authors (JF) noticed a wall chart entitled 'Insect.' It was included in a book that Renato had purchased in California USA. At the time, Renato was unaware that the book's author was Laurence Mound. An internet search revealed that Mound has published several children's books on insects, some translated into several languages (Table 1). One of them, 'Megabugs, The Natural History Museum Book of Insects,' was based on the Megabugs exhibition at the Natural History Museum, London, UK. It looks 'deep into the mysterious world of these strange and fascinating creatures, and explains the work of scientists to understand them.'

TABLE 1. Title, author(s), year of publication and publisher of books for children by Laurence Mound.

\begin{tabular}{|c|c|c|c|}
\hline Title & Author(s) & Year & Publisher \\
\hline Insect & L. A. Mound & $1990,2004,2007$ & $\begin{array}{l}\text { Eyewitness Books } \\
\text { DK Publishing, Inc. }\end{array}$ \\
\hline Paper Predators Spider and Fly & L. A. Mound & 1993 & Dell Publishing Co. \\
\hline Amazing Insects & L. A. Mound & 1993 & Random House Children's Book \\
\hline $\begin{array}{l}\text { Megabugs: The Natural History } \\
\text { Museum Book of Insects }\end{array}$ & L. MacQuitty \& L. A. Mound & 1995 & Random House \\
\hline Insectos - una Miniguía & L. A. Mound and Steve Brooks & 1995 & $\begin{array}{l}\text { Casa Autrey, División } \\
\text { Publications, México }\end{array}$ \\
\hline Insectes & L. A. Mound & 2003 & Mass Market Paperback \\
\hline 1001 Datos Sobre Insectes & L. A. Mound & 2003 & Molina \\
\hline Pocket guides: insects. & Mound, L.A. \& Brooks, S.J. & 1995 & Dorling Kindersley: London \\
\hline
\end{tabular}

The Megabugs exhibition was part of an initiative by the Museum's Board of Trustees to update the exhibitions and modify public perception of the Museum that led to a vast increase in visitor numbers (Fortey 2008). A 'business-first' philosophy was pressed upon public services during the Margaret Thatcher years. Many of the museum's scientists resented the change, but Laurence Mound welcomed the opportunities to educate the public. His interest in writing children's books is to motivate and educate a new generation to study insect diversity. A discussion with JF that occurred when LM visited Florida in 1998 revealed his intensity in educating children about biodiversity my father encouraged me to think, to use my imagination, and to challenge the thinking of others. He facilitated my interest in natural history and, in particular, insects. When I told Laurence this, he jumped up excitedly exclaiming 
that, "Now it is YOUR TURN!" He left an autographed copy of Megabugs, The Natural History Museum Book of Insects as a house-guest gift, obviously intended for my young son and I to use upon his departure.

Laurence Alfred Mound was born in Willesden, London, England on 22 April 1934. During the war years, he was evacuated from London. He was awarded a scholarship to Warwick School, reputedly the second oldest public school in England, where he remained from 1945 to 1953. His earliest ambition was medical school, but no school accepted him since he was forced to admit during interviews that adherence to the Hippocratic Oath was not his ambition. Apparently, he was interested in understanding why we die. He attended Sir John Cass College, University of London from 1953 to 1957, specializing in marine biology. His interest was the cultivation and harvest of marine foods. He floated around for a different professional interest after becoming disillusioned with the practicality of the question, "Why can't we cultivate and harvest marine foods as we do terrestrial foods?" He accepted an offer from Her Majesty's Colonial Office to study agricultural entomology, and was awarded the Diploma of Imperial College, London in Economic Entomology in 1958 and the Diploma of Tropical Agriculture from the Imperial College in Tropical Agriculture in Trinidad in 1959. This training was rather broad including the physiology of insecticide resistance, the identification of tropical weeds and grasses, the problems of drying grain, the control of rats, the grafting of buds onto rubber plants, and the life history of whiteflies (Mound 2002a).

From 1959 to 1961, Laurence Mound was an entomologist with the Nigerian Federal Department of Agricultural Research, Ibadan, studying whitefly vectors of crop virus diseases (Fig. 1). Several of the locally grown crops

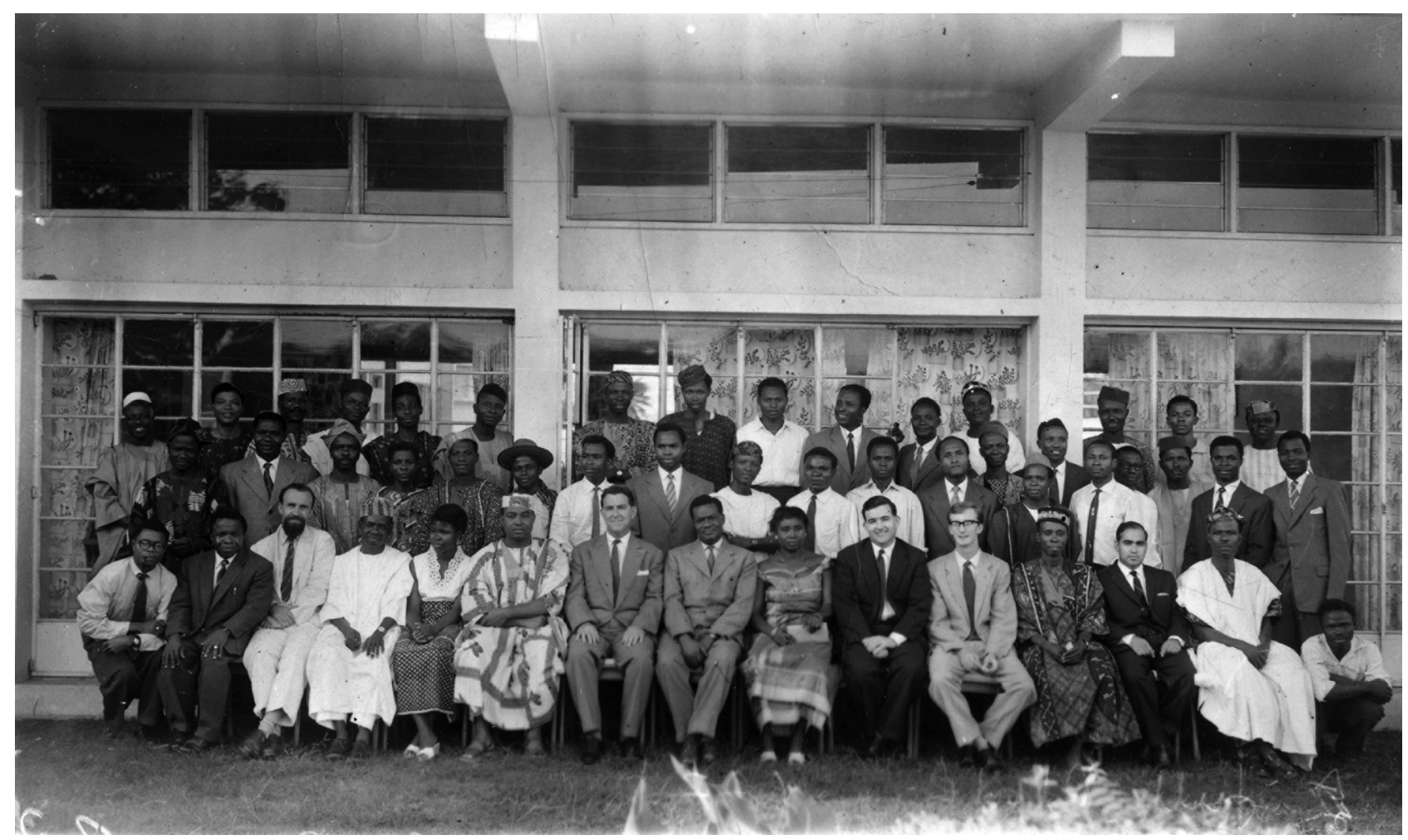

FIGURE 1. Laurence Mound's first employment as an entomologist for the Federal Department of Agricultural Research, Ibadan, Nigeria in 1960.

were damaged by different-looking whiteflies. He conducted intensive studies on variation within and between populations, including mass rearing of inbred lines on different crops (Mound 1963). He cultivated his musical interests, playing the male lead, Danilov, in the Merry Widow, staged at the University of Ibadan in 1961. He also played the violin in the orchestra for other operettas such as Lilac Time. In 1961, he was awarded a Rockefeller Studentship to study whiteflies at the US National Museum in Washington and at agricultural research institutes in California. From 1961 to 1964, he was an entomologist with the Empire Cotton Growing Corporation studying whitefly effects on cotton lint in Sudan. Claims of stickiness on cotton lint resulted in him visiting cotton mills in Europe to assess the importance of the problem (Mound 1965a). His work in Sudan provided an appreciation of the 
influence of environmental parameters on insect behavior (Mound 1962a). Two periods at the BMNH in London had resulted in development of an interest in biological diversity, the endless variety of living creatures, and this led to an interest in taxonomy (Mound 1965b). Furthermore, he came to understand that in dealing with variable pest species, taxonomy is not just about describing species, but more importantly, about understanding patterns of variation in morphology, behavior, life-histories, disease-vector ability, and host-plant relationships (Mound 2002c). His research on whiteflies was prescient to later understandings of biotypes and cryptic species as revealed by molecular biology (Perring et al. 2001). One can imagine what his aggie colleagues thought about his research on a pyralid moth in ant nests (Mound 1962b) or the role of extra-floral nectaries of cotton (Mound 1962c)!

The scientific community had taken notice of these insightful accomplishments. Laurence was appointed to the BMNH in London in 1964 as Senior Scientific Officer responsible for whitefly and thrips collections, but the clear focus of his research was the Thysanoptera. When questioned about this, he replies that he found thrips people more interesting than whitefly people! In 1969, he was promoted to Principal Scientific Officer, Head of Hemiptera Section. His early research was mostly on the taxonomy of thrips, but his journal publications included papers on whiteflies (Mound 1966a, 1967a) and aphids (Mound 1969a). The Thysanoptera were a poorly known and little understood group of insects - thrips were best known as the model organisms used by Andrewartha \& Birch (1954) to support their ideology that regulation of animal populations was independent of population density. Only general information was available concerning thrips biology (Priesner 1965). Faunistic accounts were available for North America (Stannard 1957, 1968) and a checklist for South Africa (zur Strassen 1960), but the identification key to world genera by Priesner (1949) was seriously ineffective. Many species were described by authors who spent inadequate time in the field and who failed to appreciate the phenotypic plasticity within species, and taxonomic problems were aggravated by poor preparation of microscope slides. However, the unusual biology of the group was beginning to draw the interest of ecologists such as Trevor Lewis at the Rothamsted Experimental Station in Harpendon in the United Kingdom, who provided information about thrips and their biology to W. D. Hamilton at Imperial College. The thrips 'extraordinary sex ratios' were of great interest at the time in developing theories about kin and group selection (Hamilton 1967).

Laurence Mound began his museum career with an overview of the taxonomic work by the English specialist, R.S. Bagnall (Mound 1968c) whose collections were in London. But Laurence soon returned to travelling and field work: Australia, the USA, South Africa, and New Zealand in 1967 and 1968; the USA, Jamaica, and Trinidad in1970; Malaya and Java in 1973. He studied thrips collections in 1966 at Frankfurt with Richard zur Strassen and at Linz with Herman Priesner (Fig. 2) and fulfilled administrative duties for international entomological organizations (Fig. 3). He studied numerous taxa of thrips during this period, including Hercinothrips (Mound 1966b), Taeniothrips (Mound 1966c), Thrips (Mound 1967b), the Australian Aeolothripidae (Mound 1967c, 1972a), Synaptothrips (Mound 1968a), Scirtothrips (Mound 1968b), Australian Phlaeothripidae (Mound 1969b), Heliothrips (Mound 1970b), Mecynothrips (Mound 1971b), Allothrips (Mound 1972b), Macrophthalmothrips (Mound 1972c), Sedulothrips (Mound \& O'Neill 1972), the Australian Chirothrips (Mound \& Palmer 1972), and Nesothrips (Mound 1974a). He initiated SEM studies on the feeding stylets of thrips (Mound, 1971c), and the remarkable coiled stylets of Casuarina thrips (Mound, 1970c). The taxonomy of the Merothripidae (Mound \& O'Neill 1974) was examined and he studied spore-feeding thrips (Mound 1974b). He published checklists, including a catalogue of the West African Thysanoptera (Pitkin and Mound 1973), the thrips of Lord Howe Island (Mound 1999a), the Soloman Islands (Mound 1970), Panama (Mound and Palmer 1992), and Heard Island (Green and Mound 1994).

Laurence Mound's research became progressively motivated and directed by hypothesis-driven questions. To this end, he studied the zoogeographical distribution of whiteflies (Mound 1984) and the geographical distribution in Thysanoptera (Mound 1983b). Much of his research involved systematic studies, including Mound (1977), Mound et al. (1980), Bhatti \& Mound (1980), Mound \& Palmer (1981a), Mound \& Walker (1982a), Mound \& Gauld (1982), Mound \& Palmer (1983a), Palmer \& Mound (1985), Mound \& Palmer (1986), Mound (1989), and Mound (1991a). He conducted field work in New Zealand, Singapore, and Hong Kong in 1979, China and Japan in 1980, Fiji, Tasmania and New Zealand in 1982, Panama and Costa Rica in 1983, Canada and the USA in 1984, Australia in 1985, Kenya in 1986, and Costa Rica in 1989, 1991, and 1993. Examples of the many papers from the various taxa of thrips studied during this period include Mound (1976a), Mound \& Palmer (1982), Mound (1983c), Brothers \& Mound (1985), and Mound (1990), also the accounts of the New Zealand thrips fauna (Mound \& Walker, 1982c and 1986), and the first checklist of Australian Thysanoptera (Mound \& Houston, 1987). He pub- 
lished papers on thrips biology including antennal aberrations (Mound \& Walker 1982b), sub-social behavior (Mound \& Palmer 1983), sexual dimorphism (Mound 1987), and secondary sexual character variation and fighting behavior (Mound 1991b). His long experience of museum work led to him being employed to advise on museum insect collections and identification services in several places, including Greece in 1974, India in 1979, and Taiwan in 1991.

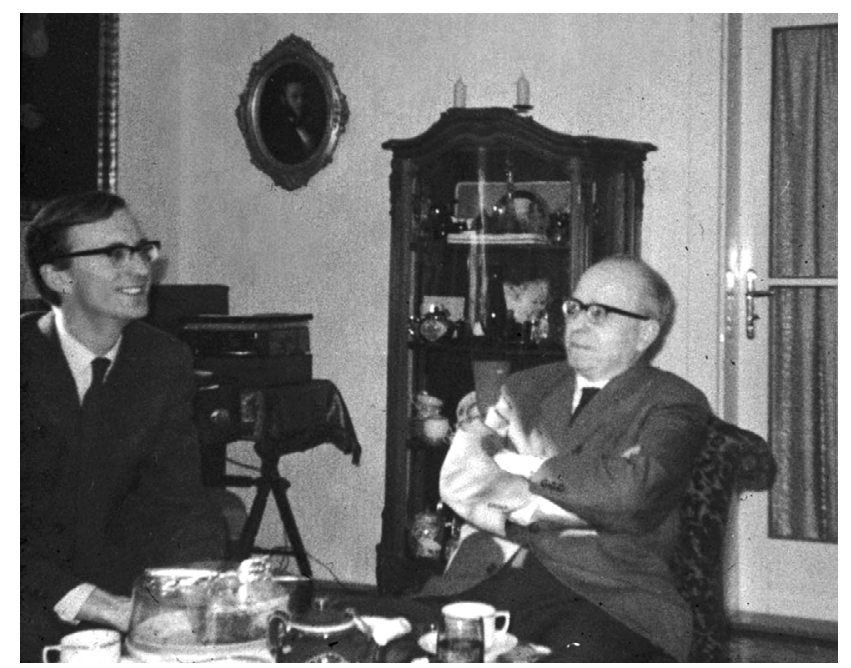

FIGURE 2. Laurence Mound, a fresh and "larviform" thrips worker with Herman Priesner, at Priesner's home in Linz, Austria, 1966.

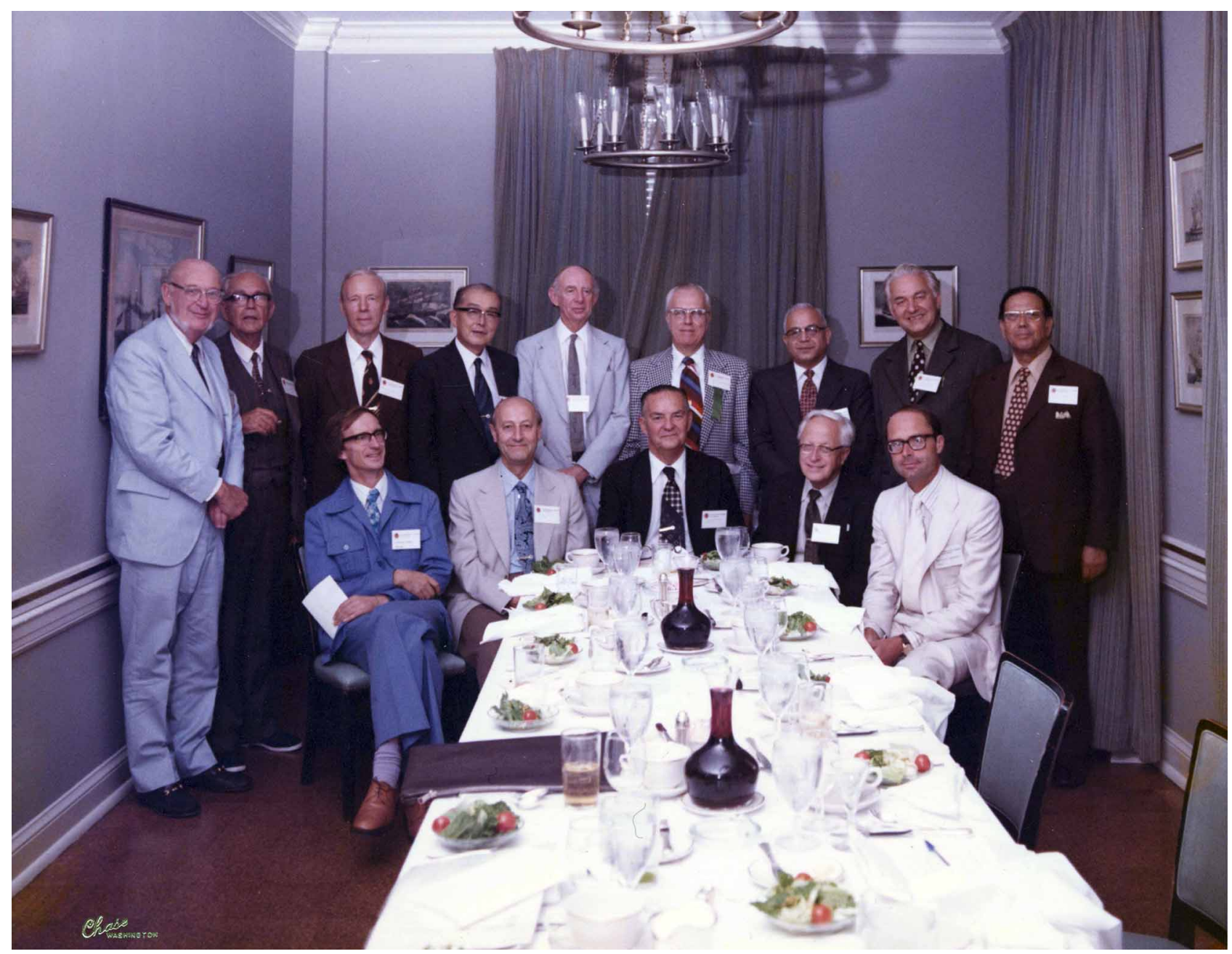

FIGURE 3. Washington, D. C., 1976, just elected as Honorary Secretary/Treasurer of the Permanent Committee for International Congresses of Entomology. Mound seated at left with Paul Freeman, his predecessor; standing next to him Ray Smith (California, USA); seated at the right is Baccio Baccetti (Italy); Doug Waterhouse (Australia) standing in the center. 
The practical applications of Laurence Mound's taxonomic work cannot be emphasized enough. His studies have helped with species identifications in important pest groups, especially Scirtothrips, a genus of notoriously difficult to identify pests with important quarantine implications when detected (Hoddle et al. 2008; a,b; Mound \& Palmer 1981b; Rugman-Jones et al. 2006). Understanding and documenting the diversity of Scirtothrips has received considerable research attention because although this genus is reasonably speciose relatively few are pestiferous, and those that are pests may exhibit either polyphagy, oligophagy, or even monophagy (Hoddle \& Mound 2003; Palmer \& Mound 1983; Mound 2009c; 2010a; Mound and Stiller 2011). Similar taxonomic insight has been provided by work on Heliothrips species, especially H. haemorrhoidalis (Mound 1970b; 1976b; Mound \& Monteiro 1998; Mound et al., 2001). Regulators, and quarantine and border inspection officials have benefited from surveys and identifications, as this rather "routine" work has alerted them to the arrival of new pest species (Houston et al. 1991; Mound 1998; Mound and Walker 1987; Mound et al. 1996), or potential new pests that could be moved on popular ornamental plants (Mound and Marullo 1994). Just as importantly, the absence of quarantine pests like Caliothrips fasciatus (Hoddle et al. 2006) has been determined for Australia through time spent in the field making systematic collections and for China by forensically unraveling identification and curation errors (Mound et al. 2011). Biological control programs have benefited from Laurence's recent taxonomic work on predatory Scolothrips (Mound 2011; Mound et al. 2010a) and Franklinothrips (Mound and Reynaud 2005) and phytophagous thrips that have potential as weed biocontrol agents have been identified (Mound and Zapater 2003; Mound and Pereyra 2008; Mound et al. 2010b).

When thrips, whiteflies, and the viruses they vector emerged as great threats to global agriculture in the 1980s, Mound was recognized as a world authority on both groups. His pioneering research into patterns of variation in morphology, behavior, life-histories, disease-vector ability, and host-plant relationships was critical to understanding the difficulties of management and in shaping the world's response. Publications include Mound (1973), Mound \& Halsey (1978), Mound (1983a), Bink-Moenen \& Mound (1990), Mound \& Teulon (1995), and Mound (1997). He became much sought after to provide direction and focus to problems in the taxonomy and management of these pests, and he has traveled throughout the world lecturing at universities, addressing professional organizations, conducting identification workshops, and visiting field sites. He enjoys learning about local cultures, and he has amassed decades of interesting experiences (Figs. 4, 5, 6, 7, 8). In 1993, he delivered the opening lectures at the Colombian Entomological Society in Cali (Mound 1993a, b). In between this activity and visiting greenhouses in the flower industry, he found himself traveling around Cali on a chivas with a bottle of aguardiente hanging around

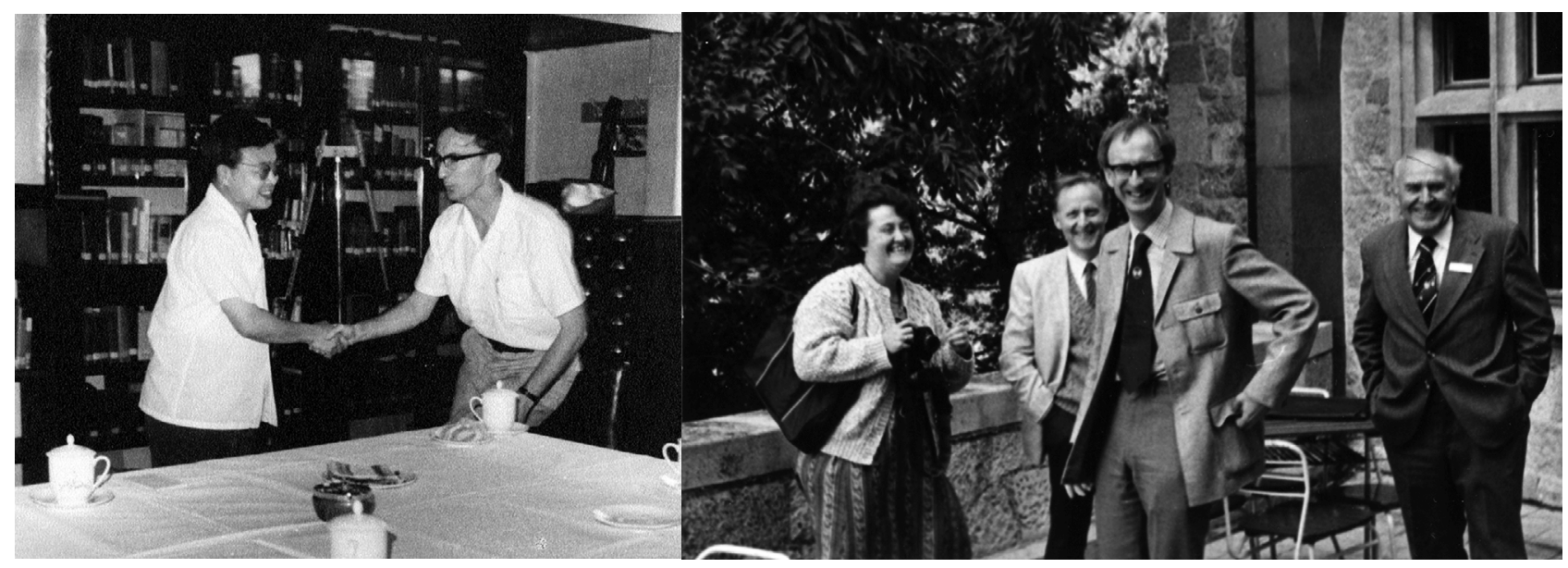

FIGURE 4. China, 1980; Mound being greeted in Shanghai as leader of delegation of entomologists from British Museum Natural History, London.
FIGURE 5. Smolenice, Czechoslovakia, 1985, Congress of European Thysanopterists. Laurence Mound with Jenny Palmer, Trevor Lewis, and Jaroslav Pelikan.

his neck. In 2000, he visited Chile to study the dynamics of global populations of Frankliniella occidentalis and the effects of this invasive flower thrips on the native species of flower thrips (Ripa et al. 2009). He was persuaded to climb La Campana mountain in Chile with JF on the same trail used by Darwin during the voyage of the H. M. S. 
Beagle (Darwin 1937), and collected thrips near the summit (Fig. 9). On the way down, he somehow slipped on some loose gravel over a very steep and long cliff. Fortunately, he landed on a rock a number of meters below, but then, uncharitably, claimed that he was pushed. Certain Chilean government officials were horrified that such a famous scientist, scraped and bruised, nearly perished on a visit to their country. More recently on a visit to Germany, Laurence fell heavily while collecting thrips with Kambiz Minaei in the rockery of the botanic garden at Halle. Happily he was rescued by an attractive young lady, who not only called an ambulance but carefully carried his useless arm to the waiting stretcher.

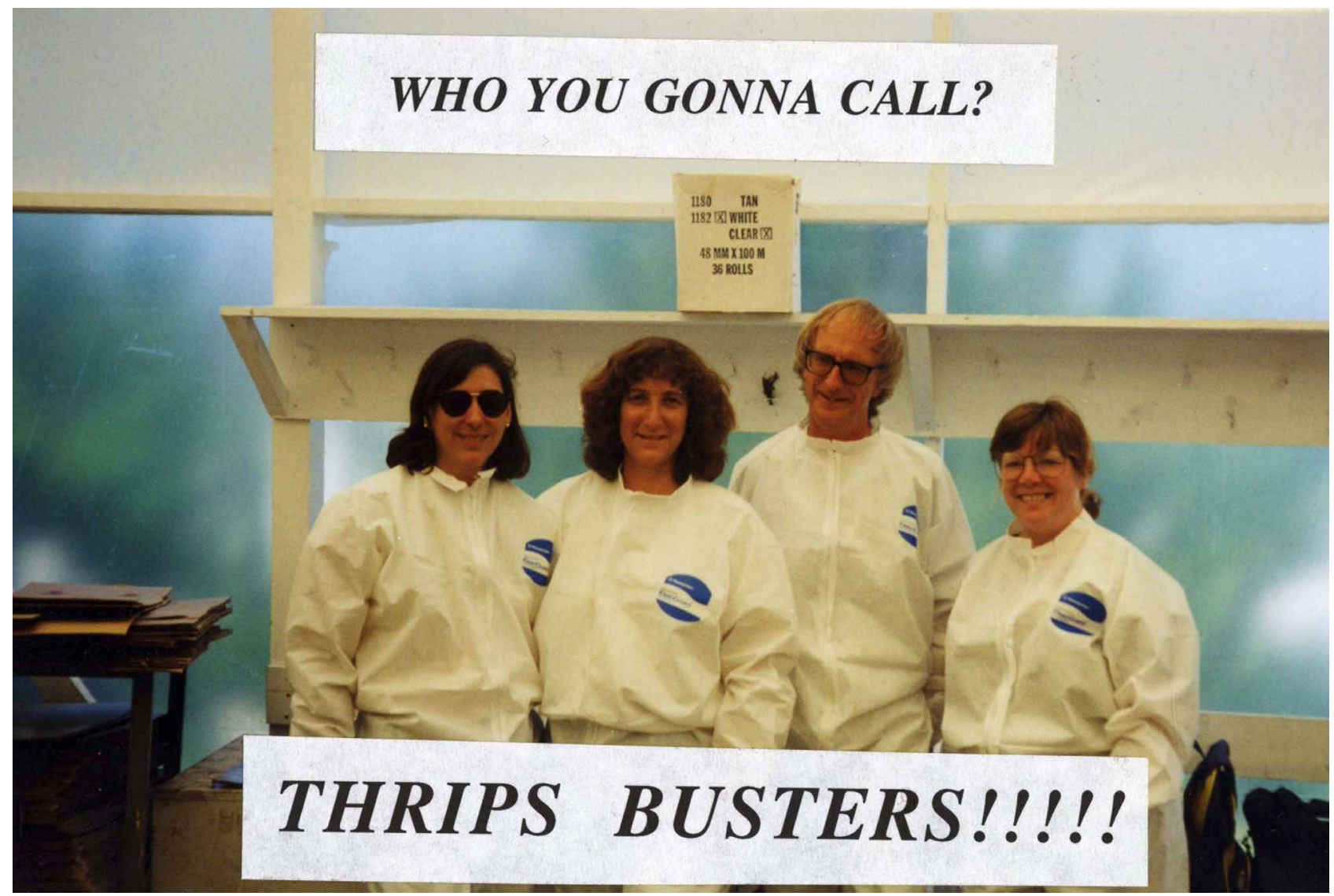

FIGURE 6. California, 1997. Laurence Mound with Diane Ullman and colleagues at the University of California, Davis.

In the 1980s and 1990s, thrips were still an obscure group of insects, but a growing number of scientists were becoming interested in studying them. The international trade in plants resulted in the emergence of a number of invasive species as pests; many of them were new species. This emergence necessitated the training of plant quarantine officials and management practitioners in their identification. The development of keys suitable for these users was a serious challenge that Laurence Mound has worked to rectify. Thrips are small, and their morphological characters are sometimes difficult to observe even with properly prepared specimens and high-quality microscopes. Palmer et al. (1989) and Mound and Kibby (1998) were the first illustrated guides to species of Thysanoptera for the practical user. The second was published to remove the problems posed by the first for some users in that it required fluency in English and familiarity with the use of dichotomous keys. Laurence Mound was quick to adopt the latest in computer technology (Lucid Technology), publishing Moritz \& Mound $(1996,1998)$ and Moritz et al. (2001, 2004). The incompatibility of these cd-roms with the operating and security systems of many computers was a recurrent problem. Hoddle et al. (2008b), a key to the thrips of California, is fully and freely available on the internet, and overcame many of these end-user problems. The thrips of California is a multi-entry interactive key, which includes factsheets on over 200 species of native, exotic, and potentially invasive thrips of importance to California. The interactive thrips glossary is especially useful for the novice, and it is richly illustrated with Automontage photomicrographs of specimens. 


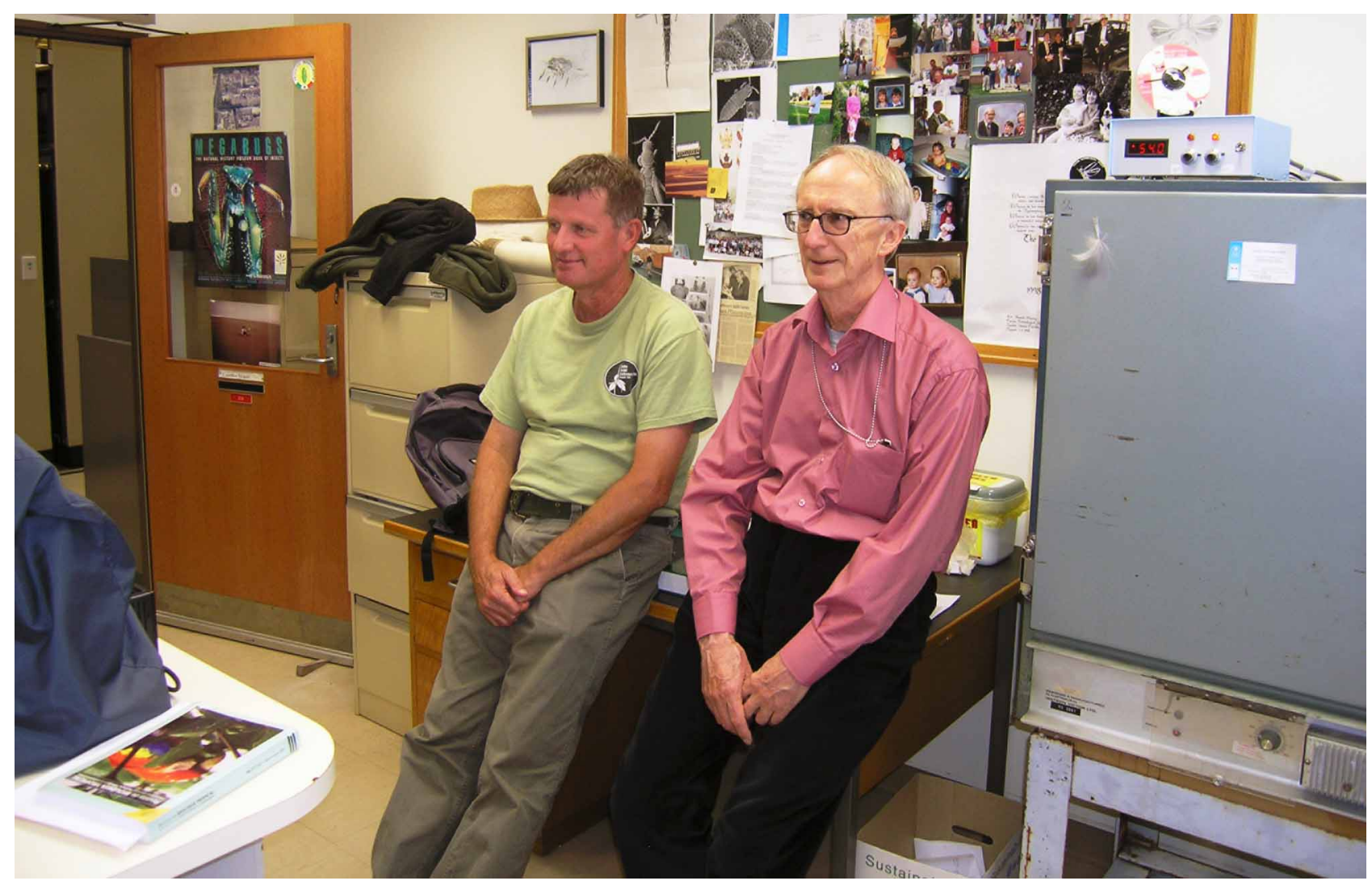

FIGURE 7. Joe Funderburk and Laurence Mound in Laurence's Lab at CSIRO, Black Mountain, Canberra Australia, 2009.

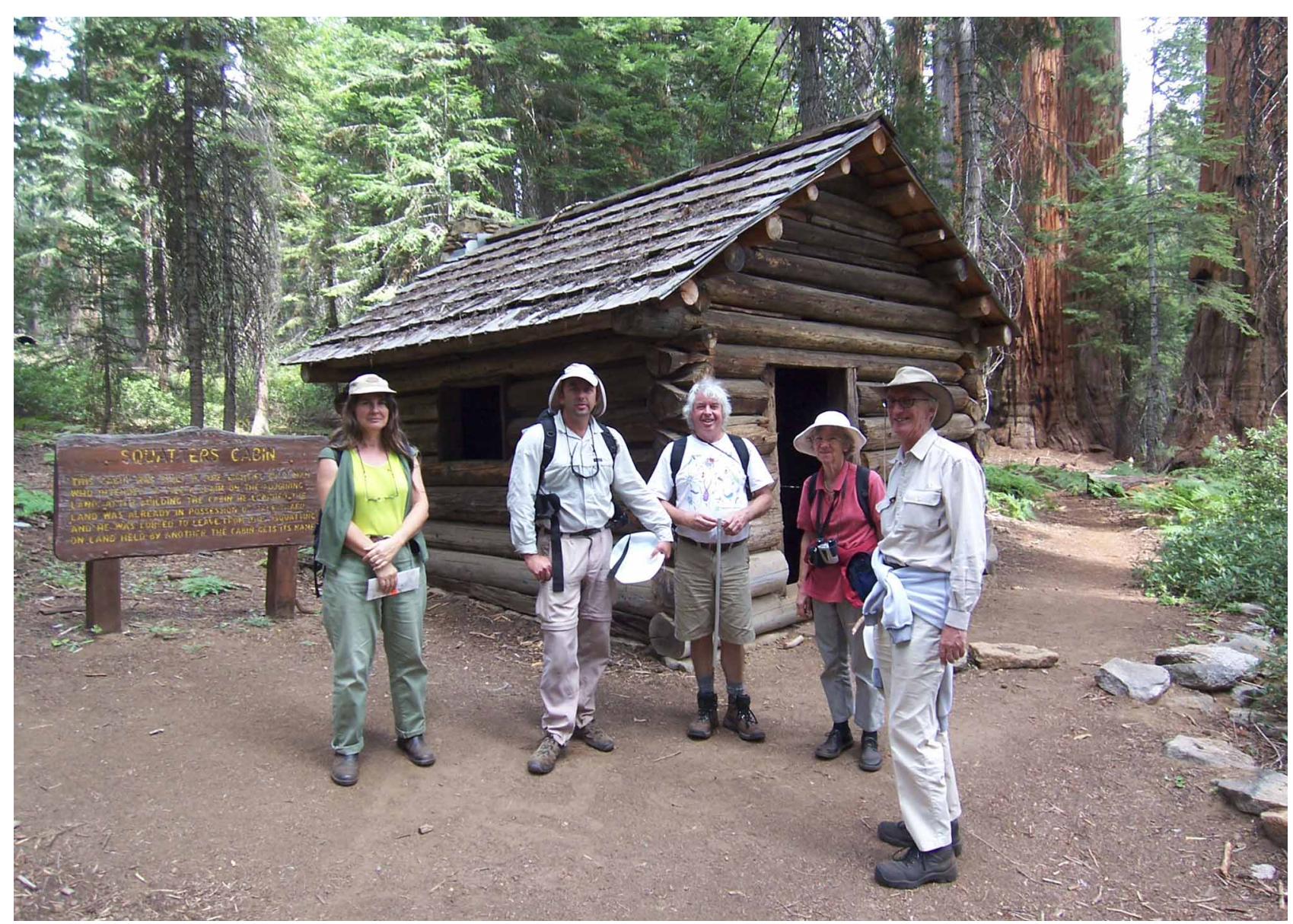

FIGURE 8. Penny Gullan (left), Mark Hoddle, Peter Cranston, Alice Wells, and Laurence Mound (right) exploring Sequioa and Kings Canyon National Park in California, 2008 (photo by Christina Hoddle). 


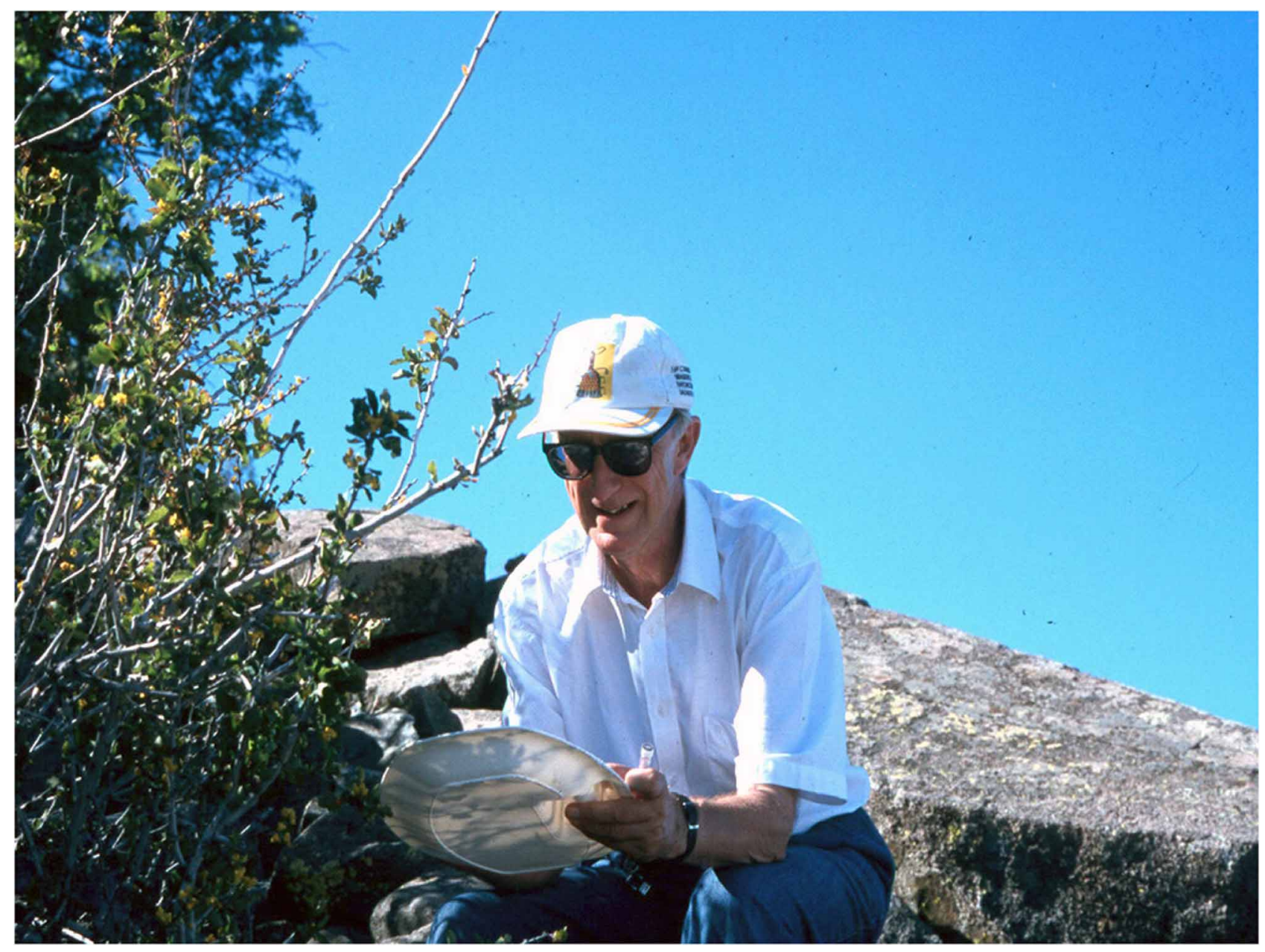

FIGURE 9. Laurence Mound collecting thrips on La Campana, Chile, 2000.

In 1975, Laurence Mound was appointed Deputy Keeper, Department of Entomology at the British Museum of Natural History, and promoted to Senior Principal Scientific Officer. Also in that year he was awarded the degree Doctor of Science by the University of London. In 1981, he was appointed Keeper of Entomology, as Deputy Chief Scientific Officer, and in 1990 he was appointed Honorary Professor, University of Wales in Cardiff. Outside entomology, through the 1970s and 1980s, he sang with various choirs in London that performed the usual choral repertoire from Faure and Verdi to Charles Ives.

In the early days of the (now) Natural History Museum, collections of animals and plants were compiled or patronized by wealthy aristocrats and other wealthy dilettantes. A certain kind of contemporary recognition and future immortality could be ensured by compiling or endowing collections. This fashion was coupled with the expansion of the British Empire; the British thought they had a right and a duty to collect. The size and scope of the collections was a matter of pride, and a reflection of the might of the nation. Scientists were hired who spent their careers collecting representatives of a particular group. These specialists employed the most basic kind of description and naming with perhaps some systematic analysis and the construction of evolutionary trees. The fundamental science carried on behind the scenes eventually became the most difficult to fund (Fortey 2008), and this erudite and scholarly work contrasted markedly with hypothesis-driven research; the latter was regarded as real business. Early in his tenure at the Museum, Laurence Mound developed a document with Victor Eastop, the aphid specialist, 'Why are we here?' Over a twenty year period the question this document posed became the focus of change. The situation at the Museum was akin to the situation when Francis Bacon, credited with the invention of the experimental method, was a student of philosophy at Trinity College, Cambridge. There was a need for a transformation in scholarly learning based on observation, experimental methods, and inductive reasoning (Ferris 2010). The Mound and Eastop document was a criticism of taxonomic practices generally, and formed the basis for many subsequent decisions on management of insect collections and on targeted research. 
In 1981, the BMNH Entomology Department had about 25 million insects, an annual income equivalent to \$US4 million, and an annual salary bill equivalent to \$US3 million (Mound 2002a). As Keeper, Laurence Mound posed the following questions. What benefit did the taxpayer obtain from such a huge investment? What were the objectives of the department? Were cost-effective methods being employed to achieve the objectives? What impact did the studies have on British science and the Commonwealth in general? As a result, taxonomic studies were shifted to the needs of other members of the community, rather than the needs of other museums. This included crop protection, human and veterinary medicine, and nature conservation. Taxonomy was viewed as vital to address the biodiversity crisis (Gaston and Mound 1993). The responsibilities of the Museum changed and the possibilities that this change brought began to be explored (Mound 1992).

Ron Hedley, Director of the British Museum of Natural History from 1976 to 1988, was the last Director to be recruited from the ranks of museum scientists. Although he resisted the changes wrought by the Thatcher government, he made an administrative move that changed the way the museum was funded. Science had to pay its way, and so reform was at hand. The capacity to secure funding was regarded as a measure of success for the scientists, whereas in 1967 Laurence Mound had been instructed not to seek external funding; the Museum was considered financially self-sufficient; external funding might bring conflicts of interest. By the late 1980s it was very hard to win grants to support taxonomic studies (Fortey 2008), the lack of hypothesis testing being almost lethal to securing external funding. Further changes came under Neil Chalmers, former Dean of Science at the Open University, who was appointed Director by the Trustees in 1988. His appeal was as an administrator; scientific distinction or scholarship was regarded as less important. Soon began the 'night of the long knives.' Laurence had to reduce the entomology staff establishment by $30 \%$, a challenge that was difficult, stressful, and caused great resentment amongst all involved.

Laurence Mound left London and retired from the Museum in 1992. During his "paid" career up to 1992, he published 94 refereed journal articles, 1 book, and 9 book chapters (not including the children's books). In the "retirement" period spanning 1992 to 2010, he published an additional 167 refereed journal articles, 3 books, and 12 book chapters (Fig. 10a). Some simple statistics summarize this productivity; from 1961 to 2010 Laurence has published an average of $6.06 \pm 0.60$ ( \pm SE) documents per year. During the "paid" period 1961-1991 publications averaged $3.32 \pm 0.40$ per year, this rate trebled during the retirement period 1992-2010 with publications averaging $10.81 \pm 0.58$ per year! A Web of Science Citation Search indicates that between 1966 to 2010 Laurence's research papers were cited at least 1,286 times, and $80 \%$ (i.e., 1,033) of these citations occured after 1992, a four fold increase in the citation rate prior to 1992 (Fig. 10b). This level of productivity is truly astonishing, even more so when you consider the amount of time, energy, and money spent collecting material, preparing slides, traveling, giving professional talks, lecturing, reviewing and editing articles for colleagues and co-authors, running training and identification workshops, and studying the latest literature. So, why is Laurence still working despite being retired? He claims that the same driving questions remain to motivate him (Mound 2002a): Why are there so many species of insects, yet so few species of thrips? Why so many at one place but so few at another? Do environmental and host plant factors drive the astonishing levels of morphological variation seen in single species? If so why? Why are so few thrips vectors of plant viruses, but those few so successful? Why so many thrips on Acacia trees in Australia? These questions, despite being asked often over a considerable period of time have not been exhausted, and simple as they are, continue to offer rich and meaningful discoveries because they have deep underlying complexity. Most importantly, every day there is something new to discover.

In 1992, Laurence received a two-year research contract from the Natural History Museum, London that was intended to support an introduction to the Thysanoptera of Costa Rica. The geographical area covered was extended to review the Neotropical thrips fauna at family and genus level. Mound \& Marullo (1996) was the resulting publication, the "go to and must have" book on thrips in this area of the world. This book includes keys to the species of many genera, derived from the available material and Laurence's experience. The recorded species are listed when keys were not possible. He studied the type material for almost all of the keyed species. Identification keys are provided to 92 genera of the Terebrantia and 135 genera of the Tubulifera. The number of species group names listed is 1,669. Taxa described included three new genera and 49 new species. Mound \& Marullo (1996) was based on his field studies in Costa Rica, Panama, Jamaica, Trinidad, Colombia, and Brazil.

Upon the completion of this Central American project, much of Laurence Mound's attention was directed again at the Australian thrips fauna. He studied gall-inducing thrips in northern Australia in 1993 under a National Geographic Grant to B.J. Crespi, and in 1994 he contracted with the Australian Biological Resources Study to prepare 
a Thysanoptera catalogue for Australia (Mound 1996). Then, after a visit to the University of Sao Paulo at Piracicaba, Brazil, and a few months as a visiting scientist at the Taiwan Agricultural research Institute, he accepted in 1995 a 12-month CSIRO McMaster Fellowship in Canberra, eventually being named Honorary Research Fellow, CSIRO Division of Entomology, in 1996. He worked in the field in many parts of Australia from Melville Island to Tasmania and Lord Howe Island to the Pilbara in the far north west of the continent. This field work included a study on the pollination of the Central Australian cycad, Macrozamia macdonelli, by a basal clade thrips (Mound and Terry 2001).
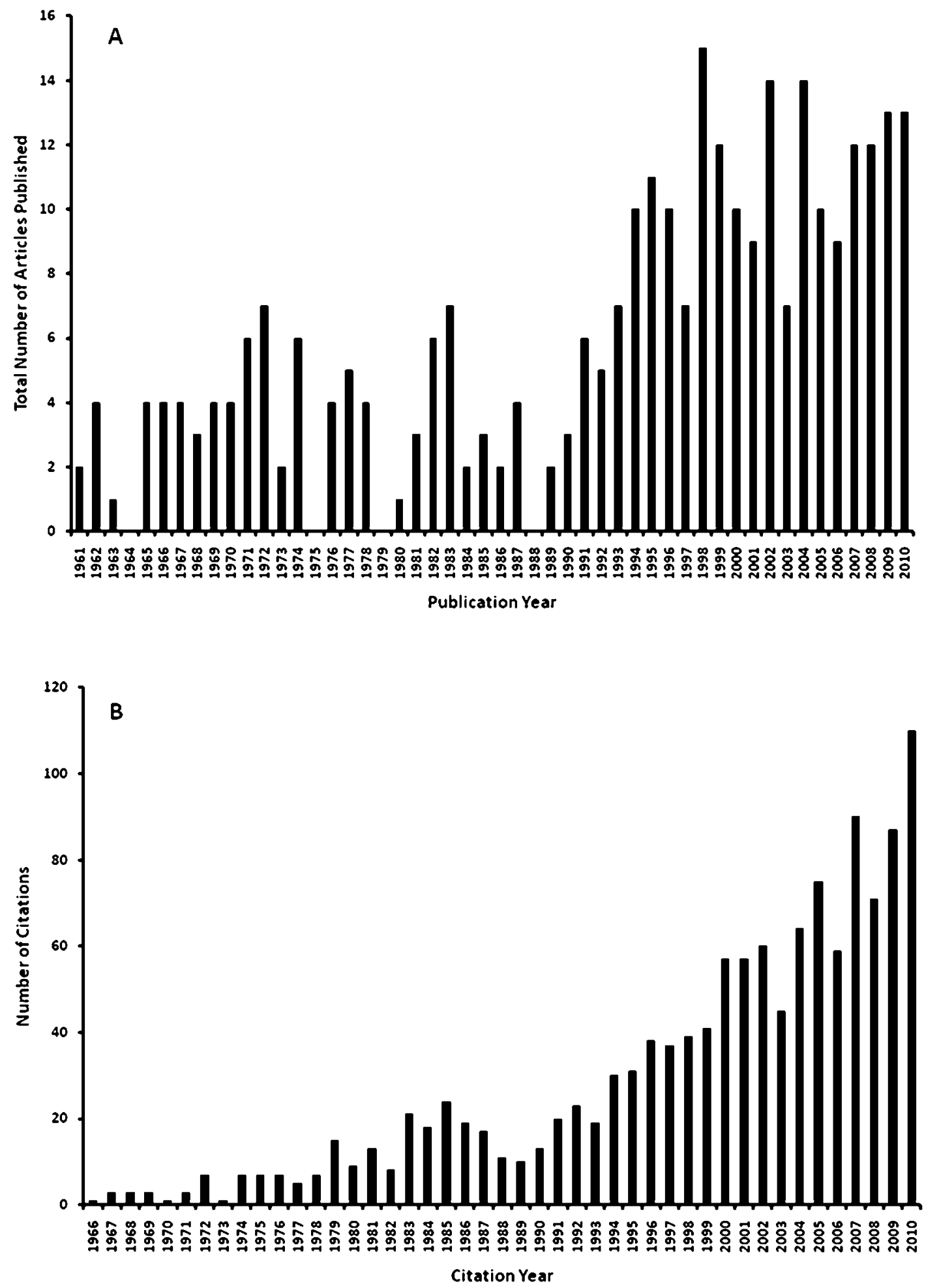

FIGURE 10. (A) Publication and (B) citation data for Laurence Mound. A full list of Laurence Mound's publications is available on the web: http://www.ento.csiro.au/thysanoptera/LAM_pubs.pdf 
Laurence has lived in Australia for over fifteen years, working productively and generally collaboratively (Mound et al. 1996 - Phlaeothripidae; Marullo \& Mound 1997- Australothrips; (Mound \& Marullo 1998 Aeolothripidae); (Mound \& Morris 1999 - Carcinothrips; Mound 1999 - Dendrothripinae; (Mound \& Moritz 2000 - Corroboreethrips; (Mound 2002b, 2008a - thrips and their host associations in Australia; Gillespie et al. 2002 - Parabaliothrips; Hoddle \& Mound 2003 - Scirtothrips; Mound \& Masumoto 2005 - Thrips; Mound \& Minaei 2006, 2007 - fungus-feeding Phlaeothripinae; Mound 2007 - Idolothripinae; (Mound \& Tree 2009 Sericothripinae; Mound \& Masumoto 2009 - Anaphothrips; Mound 2009a - Panchaetothripinae; Pereyra \& Mound 2009 - Cranothrips; and Pereyra \& Mound 2010 - Desmothrips. He continues to publish studies on insect diversity (Mound 2002a; Pinent et al. 2003; Mound 2004a,b; Mound \& Reynaud 2005; Mound 2006; Goldarazena \& Mound 2006) and this productivity is documented in the lists of genera and species he has described (see Tables 2 and 3). Many of these studies include aspects of the biology and behavior of thrips (e.g. Funderburk et al. 2008, Tyagi et al. 2008, Tree \& Mound 2009). The latest examples of his contributions to checklists include Mound \& Ng (2009), Minaei \& Mound (2008), Diffie et al. (2008), Hoddle et al. (2004, 2008d), Hoddle and Mound (2011), and Tillekaratne et al. (2007). Laurence regards collaboration as a vital element in his productivity. Despite advice to the contrary, both from supervisors and other taxonomists, a high proportion of his publications have involved co-authorship. Laurence cheerfully acknowledges the debt he owes to the very large number of coauthors with whom he has worked, from Jenny Palmer, Brian Pitkin and Sheila Halsey in the 1960s and '70s, to Masami Masumoto, Gerald Moritz, Desley Tree, Alice Wells and Hongrui Zhang in the most recent decade.

TABLE 2. List of 90 Thysanoptera genera described by Laurence Mound over the period December 1967 to December 2010.

\section{STENUROTHRIPIDAE}

Heratythrips Mound \& Marullo, 1998: 88

FAURIELLIDAE

Parrellathrips Mound \& Marullo, 1998: 83

\section{AEOLOTHRIPIDAE}

Andrewarthaia Mound,1967c: 47

Arcuthrips Mound, 1967c: 205 [= Gelothrips Bhatti]

Cycadothrips Mound, 1991a: 649

Desmidothrips Mound, 1977b: 149

ErythridothripsMound \& Marullo, 1993: 285

THRIPIDAE - PANCHAETOTHRIPINAE

Bhattithrips Mound, 1970: 44

Hoodothripoides Mound, 1970: 54

Stosicthrips Mound, 2009: 26

THRIPIDAE - DENDROTHRIPINAE

Filicopsothrips Mound, 1999b: 268

THRIPIDAE - THRIPINAE

Adelphithrips Mound \& Palmer, 1981: 160

Ameranothrips Mound \& Marullo, 1996: 88

Anaphrygmothrips Mound \& Walker, 1982: 53

Brooksithrips Retana \& Mound, 2005: 122

Cyrilthrips Tree \& Mound, 2009: 1152

Dikrothrips Mound \& Walker, 1982c: 64

Dodonaeathrips Mound \& Masumoto, 2009: 59

Gabanithrips Bhatti \& Mound, 1992: 175

Karphothrips Mound \& Walker, 1982c: 57

Kenyattathrips Mound, 2009c: 65

Labiothrips Bhatti \& Mound, 1994: 162 [= Scirtothrips Shull]

Lomatothrips Mound \& Walker, 1982c: 67

Nexothrips Marullo \& Mound, 2001: 232
Ozanaphothrips Mound \& Masumoto, 2009: 61

Pandorathrips Mound \& Masumoto, 2009: 70

Parascolothrips Mound, 1967d: 315

Psydrothrips Palmer \& Mound, 1985: 192

Retanathrips Mound \& Nickle, 2009: 62

Rhamphiskothrips Mound, 1990: 214

Yaobinthrips Zhang, Mound \& Xie, 2010: 65

PHLAEOTHRIPIDAE - IDOLOTHRIPINAE

Anaglyptothrips Mound \& Palmer, 1983: 34

Azeugmatothrips Mound \& Palmer, 1983: 82

Ecacleistothrips Mound, 2007: 54

Herathrips Mound, 1974b: 54

Malesiathrips Palmer \& Mound, 1978: 196

Minaeithrips Mound, 2007: 60

Neatractothrips Mound \& Palmer, 1983: 85

Nesidiothrips Mound, 1974b: 156

Ommatidothrips Mound, 1970d: 120

Ozothrips Mound \& Palmer, 1983: 24

Paractinothrips Mound \& Palmer, 1983: 85

Pelinothrips Mound, 1974b: 75

Peltariothrips Mound \& Palmer, 1983: 59

Phacothrips Mound, 1974a: 170

Tarassothrips Mound \& Palmer, 1983: 61

PHLAEOTHRIPIDAE - PHLAEOTHRIPINAE

Adurothrips Mound, 1994: 24

Advenathrips Morris, Mound \& Schwarz, 2000: 54

Akainothrips Mound, 1971a: 395

Akthethrips Mound, 1970c: 452

Andrethrips Mound, 1974a: 110

Apostlethrips Mound \& Minaei, 2006: 2

Baphikothrips Mound, 1970d: 90 [=Stigmothrips Ananthakrishnan]

Brakothrips Crespi, Morris \& Mound, 2004: 146

Callococcithrips Mound \& Wells, 2007: 58 
Corroboreethrips Mound \& Moritz, 2000: 710

Crespithrips Mound \& Morris, 2000: 132

Csirothrips Mound, 1971a: 398

Deplorothrips Mound \& Walker, 1986: 49

Domatiathrips Mound, 1993c: 427

Domeothrips Crespi, Morris \& Mound, 2004: 182

Glaridothrips Crespi, Morris \& Mound, 2004: 192

Godoythrips Mound \& Marullo, 1996: 275

Hansonthrips Mound \& Marullo, 1996: 279

Heligmothrips Mound, 1970c: 453

Heptadikothrips Crespi, Morris \& Mound, 2004: 198

Hexadikothrips Crespi, Morris \& Mound, 2004: 199

Iotatubothrips Mound \& Crespi, 1992: 400

Katothrips Mound, 1971a: 409

Klambothrips Mound \& Morris, 2007b: 39

Lichanothrips Mound, 1971a: 434

Majerthrips Mound \& Minaei, 2006: 7

Murphythrips Mound \& Palmer, 1983: 421
Ostlingothrips Crespi, Morris \& Mound, 2004: 267

Phallothrips Mound \& Crespi, 1992: 403

Sartrithrips Mound \& Morris, 2001: 414

Schwarzithrips Mound \& Morris, 2000: 135

Senithrips Mound \& Minaei, 2006: 9

Solomonthrips Mound, 1970d: 104

Sophikothrips Mound, 1970d: 113

Suocerathrips Mound \& Marullo, 1994: 96

Triadothrips Crespi, Morris \& Mound, 2004: 288

Truncatothrips Crespi, Morris \& Mound, 2004: 291

Turmathrips Crespi, Morris \& Mound, 2004: 292

Vicinothrips Mound \& Morris, 2000: 136

Warithrips Mound, 1971a: 453

Xaniothrips Mound, 1971a: 457

Xyelethrips Mound, 1970c: 460

Yarnkothrips Mound \& Walker, 1987: 83

Zemiathrips Mound, 2002d: 210

TABLE 3. List of 641 Thysanoptera species described by Laurence Mound over the period December 1965 to April 2011.

\section{STENUROTHRIPIDAE}

Heratythrips sauli Mound \& Marullo, 1998: 89

FAURIELLIDAE

Parrellathrips ullmanae Mound \& Marullo, 1998: 85

\section{HETEROTHRIPIDAE}

Heterothrips lewisi Mound \& Marullo, 1996: 64

Heterothrips mimosae Mound \& Marullo, 1996: 65

Heterothrips peixotoae Del-Claro, Marullo \& Mound, 1997: 1309

Scutothrips byrsonimae Mound \& Marullo, 1996: 69

\section{MELANTHRIPIDAE}

Cranothrips bellisi Mound \& Marullo, 1998: 934

Cranothrips conostylus Pereyra \& Mound, 2009: 159

Cranothrips ibisca Pereyra \& Mound, 2009: 157

Cranothrips kartus Mound, 1972a: 41

Cranothrips ravidus Mound, 1972a: 43

Cranothrips sititor Mound, 1972a: 44

Cranothrips symoni Mound, 1972a: 45

Cranothrips vesper Mound, 1972a: 46

Dorythrips jenkinsi Mound, 1972a: 51

Dorythrips wallacei Mound, 1972a: 52

AEOLOTHRIPIDAE

Andrewarthaia minor Mound, 1967c: 51 [=kellyana Bagnall]

Audiothrips senckenbergiana Mound \& Marullo, 1993: 289

Cycadothrips albrechti Mound \& Terry, 2001: 150

Cycadothrips chadwicki Mound, 1991: 650

Cycadothrips emmaliami Mound \& Marullo, 1998: 935

Desmidothrips walkerae Mound, 1977b: 151

Desmothrips aliceae Pereyra \& Mound, 2010: 311

Desmothrips barrowi Pereyra \& Mound: 2010: 315

Desmothrips broomei Pereyra \& Mound, 2010: 316

Desmothrips chirus Mound \& Marullo, 1998: 939

Desmothrips darwini Mound \& Marullo, 1998: 940

Desmothrips marilynae Mound \& Marullo, 1998: 941
Desmothrips postlei Pereyra \& Mound, 2010: 316

Desmothrips reedi Mound, 1967c: 66

Desmothrips steeleae Mound, 1967c: 66

Desmothrips stepheni Mound \& Marullo, 1998: 942

Erythridothrips cubilis Mound \& Marullo, 1993: 287

Franklinothrips basseti Mound \& Marullo, 1998: 944

\section{THRIPIDAE-PANCHAETOTHRIPINAE}

Astrothrips bhattii Mound, 1970b: 43

Australothrips aliceae Marullo \& Mound, 1997: 223

Bhattithrips borealis Mound, 2009a: 31

Bhattithrips dahmsi Mound, 1970b: 49

Bhattithrips pitkini Mound, 1970b: 48

Caliothrips tongi Mound, Zhang \& Bei, 2011: 58

Euhydatothrips okwakpami Mound, 1970b: 52

Heliothrips zucchi Mound \& Monteiro, 1998: 156

Hercinothrips aethiopiae Mound, 1965c: 244

Hoodothrips braziliensis Mound, 1970b: 54 [=lineatus Hood]

Panchaetothrips timonii Mound \& Postle, 2004: 136

Stosicthrips szitas Mound, 2009a: 27

\section{THRIPIDAE-DENDROTHRIPINAE}

Dendrothrips diaspora Mound, 1999: 261

Dendrothrips glynn Mound, 1999: 264

Dendrothrips howei Mound, 1999: 264

Edissa steinerae Mound, 1999: 266

Ensiferothrips secundus Mound, 1999: 268

Filicopsothrips wellsae Mound, 1999: 268

Pseudodendrothrips alexei Mound \& Tree, 2007: 10

Pseudodendrothrips gillespiei Mound, 1999: 272

\section{THRIPIDAE-SERICOTHRIPINAE}

Hydatothrips aliceae Mound \& Tree, 2009: 4

Hydatothrips bhattii Mound \& Tree, 2009: 7

Hydatothrips gliricidiae Mound \& Marullo, 1996: 161

Hydatothrips guanacastei Mound \& Marullo, 1996: 161

Hydatothrips volcano Mound \& Marullo, 1996: 162 
Hydatothrips williamsi Mound \& Tree, 2009: 10 Neohydatothrips barrowi Mound \& Tree, 2009: 13 Neohydatothrips bellisi Mound \& Tree, 2009: 13 Neohydatothrips hadrosetae Mound \& Marullo, 1996: 168 Neohydatothrips humberto Mound \& Marullo, 1996: 169 Neohydatothrips katherinae Mound \& Tree, 2009: 18

\section{THRIPIDAE-THRIPINAE}

Adelphithrips cassiniae Mound \& Palmer, 1981: 163 Adelphithrips dolus Mound \& Walker, 1982c: 60 Adelphithrips nothofagi Mound \& Palmer, 1981: 161 Ameranathrips herediae Mound \& Marullo, 1996: 89 Anaphothrips aptilotus Mound \& Masumoto, 2009: 15 Anaphothrips atriplicis Mound \& Masumoto, 2009: 19 Anaphothrips augustae Mound \& Masumoto, 2009: 19 Anaphothrips barringtoni Mound \& Masumoto, 2009: 21 Anaphothrips barrowi Mound \& Masumoto, 2009: 21 Anaphothrips callani Mound \& Masumoto, 2009: 23 Anaphothrips chortinus Mound \& Masumoto, 2009: 26 Anaphothrips cobari Mound \& Masumoto, 2009: 27 Anaphothrips dalbyi Mound \& Masumoto, 2009: 29 Anaphothrips desleyae Mound \& Masumoto, 2009: 30 Anaphothrips epacrida Mound \& Masumoto, 2009: 32 Anaphothrips eremophilae Mound \& Masumoto, 2009: 34 Anaphothrips exocarpoides Mound \& Masumoto, 2009: 35 Anaphothrips geijerae Mound \& Masumoto, 2009: 36 Anaphothrips geleznowiae Mound \& Masumoto, 2009: 36 Anaphothrips gillespiei Mound \& Masumoto, 2009: 37 Anaphothrips glenysae Mound \& Masumoto, 2009: 41 Anaphothrips monga Mound \& Masumoto, 2009: 42 Anaphothrips nimbus Mound \& Masumoto, 2009: 46 Anaphothrips orchis Mound \& Masumoto, 2009: 47 Anaphothrips parsonsiae Mound \& Masumoto, 2009: 49 Anaphothrips pultenaeae Mound \& Masumoto, 2009: 50 Anaphothrips walchae Mound \& Masumoto, 2009: 54 Anaphothrips westringiae Mound \& Masumoto, 2009: 55 Anaphothrips whyalla Mound \& Masumoto, 2009: 56 Anaphothrips yalgooi Mound \& Masumoto, 2009: 58 Anaphothrips zelandicus Mound, 1978: 616 Anaphrygmothrips otagensis Mound \& Walker, 1982c: 54 Anascirtothrips arafura Mound \& Wang, 2000: 330 Brooksithrips chamaedoreae Retana \& Mound, 2005: 122 Chaetisothrips chavesi Mound \& Marullo, 1996: 105 Charassothrips macroseta Goldarazena \& Mound, 2010: 3 Cyrilthrips cecidis Tree \& Mound, 2009: 1156 Dichromothrips australiae Mound, 1976: 251 Dichromothrips indicus Mound, 1976: 255 Dichromothrips nakahari Mound, 1976: 258 Dichromothrips nigeriae Mound, 1976: 25

Dichromothrips maori Mound, 1976: 256 [=spiranthidis Bagnall]

Dichromothrips viatorus Mound, 1976; 264

Dikrothrips diphyes Mound \& Walker, 1982c: 64

Dodonaeathrips eremiae Mound \& Masumoto, 2009: 60

Echinothrips selaginellae Mound, 1994: 1413

Filipinothrips ananthakrishnani Tyagi, Kumar \& Mound, 2008: 166

Frankliniella akaina Mound \& Marullo, 1996: 127

Frankliniella altura Mound \& Marullo, 1996: 128

Frankliniella cotobrusensis Retana \& Mound, 1995: 647

Frankliniella crotalariae Mound \& Marullo, 1996: 134
Frankliniella desmodii Mound \& Marullo, 1996: 136

Frankliniella hansoni Retana \& Mound, 1995: 645

Frankliniella kiesteri Retana \& Mound, 1995: 646

Frankliniella lantanae Mound, Nakahara \& Day, 2005: 280

Frankliniella lorena Mound \& Marullo, 1996: 142

Frankliniella mekokara Mound \& Marullo, 1996: 143

Frankliniella montanosa Retana \& Mound, 1995: 647

Frankliniella pasta Mound \& Marullo, 1996: 148

Frankliniella pintada Mound \& Marullo, 1996: 149

Frankliniella ramirezi Mound \& Marullo, 1996: 150

Frankliniella sanramona Mound \& Marullo, 1996: 151

Frankliniella sueoa Mound \& Marullo, 1996: 153

Frankliniella talamanca Mound \& Marullo, 1996: 155

Frankliniella vargasi Retana \& Mound, 1995: 645

Frankliniella zurqui Retana \& Mound, 1995: 647

Gabanithrips bantus Bhatti \& Mound, 1992: 178

Karphothrips dugdalei Mound \& Walker, 1982c: 57

Kenyattathrips katarinae Mound, 2009c: 67

Lomatothrips paryphis Mound \& Walker, 1982c: 67

Lomatothrips pinopsidis Mound, 2006: 13

Nexothrips delclaroi Marullo \& Mound, 2001: 234

Nexothrips perseae Marullo \& Mound, 2001: 235

Octothrips lygodii Mound, 2002b: 219 [=bhattii Wilson]

Odontothrips yunnanensis Xie, Zhang \& Mound, 2010: 55

Organothrips wrighti Mound, 2000: 11

Ozanaphothrips condaminei Mound \& Masumoto, 2009: 63

Ozanaphothrips fenarius Mound \& Masumoto, 2009: 63

Ozanaphothrips kununurrai Mound \& Masumoto, 2009: 65

Ozanaphothrips perotis Mound \& Masumoto, 2009: 66

Ozanaphothrips thulius Mound \& Masumoto, 2009: 69

Ozanaphothrips torridus Mound \& Masumoto, 2009: 69

Pandorathrips ascius Mound \& Masumoto, 2009: 72

Parabaliothrips annettae Mound \& Palmer, 1981: 166 [=montanus Girault]

Parabaliothrips newmani Gillespie, Mound \& Wang, 2002: 114

Parascolothrips priesneri Mound, 1967d: 317

Physemothrips hadrus Mound, 1978: 617

Psectrothrips palmerae Mound \& Marullo, 1996: 179

Pseudanaphothrips araucariae Mound \& Palmer, 1990a: 5

Pseudanaphothrips casuarinae Mound \& Palmer, 1990a: 3

Pseudothrips retanae Mound \& Marullo, 1996: 181

Psydrothrips kewi Palmer \& Mound, 1985: 192

Rhamphiskothrips rhipistos Mound, 1990: 216

Scirtothrips abditus Mound \& Marullo, 1996: 187

Scirtothrips akakia Hoddle \& Mound, 2003: 10

Scirtothrips astibos Hoddle \& Mound, 2003: 12

Scirtothrips astrictus Mound \& Marullo, 1996: 188

Scirtothrips bounites Mound \& Marullo, 1996: 189

Scirtothrips casuarinae Palmer \& Mound, 1983: 512

Scirtothrips drepanofortis Hoddle \& Mound, 2003: 18

Scirtothrips eremicus Hoddle \& Mound, 2003: 19

Scirtothrips euthyntus Mound \& Marullo, 1996: 190

Scirtothrips frondis Hoddle \& Mound, 2003: 20

Scirtothrips helenae Palmer \& Mound, 1983: 514

Scirtothrips ikelus Mound \& Marullo, 1996: 191

Scirtothrips kenyensis Mound, 1968b: 535

Scirtothrips kirrhos Hoddle \& Mound, 2003: 23

Scirtothrips litotetes Hoddle \& Mound, 2003: 24

Scirtothrips lumarius Mound \& Marullo, 1996: 191

Scirtothrips moneres Hoddle \& Mound, 2003: 26 
Scirtothrips mugambii Mound, 2010a: 66

Scirtothrips pan Mound \& Walker, 1982c: 46

Scirtothrips pilbara Hoddle \& Mound, 2003: 27

Scirtothrips pteridis Mound \& Marullo, 1996: 193

Scirtothrips quadriseta Hoddle \& Mound, 2003: 29

Scirtothrips solus Hoddle \& Mound, 2003: 30

Scirtothrips tenor Bhatti \& Mound, 1994: 163

Scolothrips ochoa Mound, Tree \& Goldarazena, 2010: 64

Thrips antiaropsidis Zerega, Mound \& Weiblen, 2004: 1019

Thrips aspinus Mound \& Masumoto, 2005: 15

Thrips austellus Mound, 1978: 618

Thrips coprosmae Mound, 1978: 618

Thrips darwini Mound \& Masumoto, 2005: 20

Thrips diana Mound \& Masumoto, 2005: 22

Thrips excaeletus Mound \& Masumoto, 2005: 23

Thrips hanifahi Mound \& Azidah, 2009: 64

Thrips hoddlei Mound \& Masumoto, 2005: 28

Thrips kurahashii Mound, 2010b: 9

Thrips martini Mound \& Masumoto, 2005: 36

Thrips phormiicola Mound, 1978: 620

Thrips razanii Ng, Eow \& Mound, 2010: 65

Thrips safrus Mound \& Masumoto, 2005: 45

Thrips solari Mound, 2010b: 15

Thrips tomeus Mound \& Masumoto, 2005: 52

Thrips wellsae Mound \& Masumoto, 2005: 57

Trichromothrips veversae Mound \& Masumoto, 2004: 68

Yaobinthrips yangtzei Zhang, Mound \& Xie, 2010: 68

\section{PHLAEOTHRIPIDAE-IDOLOTHRIPINAE}

Actinothrips apithanus Mound, 1991b: 941

Actinothrips retanae Mound, 1991b: 939

Allothrips bournieri Mound, 1972b: 35

Allothrips greensladei Mound, 1972b: 30

Allothrips hamideae Mound, 2007: 59

Allothrips prolixus Mound, 1972b: 30

Allothrips stannardi Mound, 1972b: 31

Anactinothrips gustaviae Mound \& Palmer, 1983b: 792

Anaglyptothrips dugdalei Mound \& Palmer, 1983b: 35

Azeugmatothrips rectus Mound \& Palmer, 1983b: 82

Bacillothrips bagnalli Mound \& Palmer, 1983b: 72

Bactrothrips pitkini Mound \& Palmer, 1983b: 74

Bolothrips italicus Mound, 1974b: 122

Carientothrips acti Mound, 1974b: 25

Carientothrips capricornis Mound, 1974b: 23

Carientothrips casuarinae Mound, 1974b: 26

Carientothrips grayi Mound, 1974b: 129

Carientothrips loisthus Mound, 1974b: 29

Carientothrips magnetis Mound, 1974b: 30

Carientothrips miskoi Mound, 1974b: 31

Carientothrips pedicillus Mound, 1974b: 32

Carientothrips pictilis Mound, 1974b: 33

Carientothrips reedi Mound, 1974b: 34

Carientothrips vesper Mound, 1974b: 35

Celidothrips lawrencei Mound, 1970b: 122

Cryptothrips amneius Mound, 1974b: 42

Cryptothrips okiwiensis Mound \& Walker, 1986: 22

Diceratothrips bennetti Mound \& Palmer, 1983b: 44

Dichaetothrips okajimai Mound \& Palmer, 1983b: 53

Dichaetothrips secutor Mound \& Palmer, 1983b: 53

Ecacleistothrips glorious Mound, 2007: 55

Emprosthiothrips bogong Mound, 1969b: 185
Emprosthiothrips brimblecombei Mound, 1974b: 51

Emprosthiothrips brittoni Mound, 1969b: 186

Emprosthiothrips csiro Mound, 1969b: 185

Emprosthiothrips epallelus Mound, 1974b: 52

Ethirothrips barretti Mound, 1974b: 94

Ethirothrips distasmus Mound, 1974b: 97

Ethirothrips sybarita Mound, 1974b: 100

Heptathrips cottieri Mound \& Walker, 1986: 24

Heptathrips cumberi Mound \& Walker, 1986: 25

Heptathrips kuscheli Mound \& Walker, 1986: 26

Heptathrips tillyardi Mound \& Walker, 1986: 27

Holurothrips collessi Mound, 1974b: 58

Machatothrips decorus Palmer \& Mound, 1978: 193

Machatothrips lentus Palmer \& Mound, 1978: 194

Malesiathrips australis Mound, 2007: 66

Malesiathrips guamensis Palmer \& Mound, 1978: 196

Malesiathrips malayensis Palmer \& Mound, 1978: 198

Malesiathrips solomoni Mound, 1970b: 116

Mecynothrips kraussi Palmer \& Mound, 1978: 205

Mecynothrips priesneri Mound, 1971b: 281

Mecynothrips minor Mound, 1971b: 282 [= priesneri Mound]

Megalothrips andrei Mound \& Palmer, 1983: 78

Minaeithrips aliceae Mound, 2007: 61

Minaeithrips driesseni Mound, 2007: 61

Neosmerinthothrips hamiltoni Mound \& Palmer, 1983: 46

Nesothrips alexandrae Mound \& Walker, 1986: 29

Nesothrips aoristus Mound, 1974a: 68

Nesothrips carverae Mound, 1974a: 71

Nesothrips doulli Mound, 1974a: 171

Nesothrips eastopi Mound, 1974a: 173

Nesothrips fodinae Mound, 1974a: 163

Nesothrips hemidiscus Mound, 1974a: 71

Nesothrips leveri Mound, 1974a: 175

Nesothrips malaccae Mound, 1974a: 164

Nesothrips melinus Mound, 1974a: 72

Nesothrips pintadus Mound \& Walker, 1986: 31

Nesothrips rangi Mound \& Palmer, 1983: 48

Nesothrips yanchepi Mound, 1974a: 75

Nesothrips zondagi Mound, 1974a: 176

Ozothrips eurytis Mound \& Palmer, 1983: 25

Ozothrips janus Mound \& Palmer, 1983: 26

Ozothrips priscus Mound \& Palmer, 1983: 26

Ozothrips tubulatus Mound \& Walker, 1986: 37

Ozothrips vagus Mound \& Walker, 1986: 38

Paractinothrips peratus Mound \& Palmer, 1983: 86

Pelinothrips brochotus Mound, 1974a: 76

Peltariothrips insolitus Mound \& Palmer, 1983: 60

Phaulothrips anici Mound, 1974a: 82

Phaulothrips barretti Mound, 1974a: 83

Phaulothrips sibylla Mound, 1974b: 84

Phaulothrips uptoni Mound, 1974b: 85

Polytrichothrips geoffri Mound, 2007: 64

Priesneriana uptoni Mound, 1974b: 44

Priesneriella gnomus Mound \& Palmer, 1983: 33

Pygothrips pygus Mound, 1974b: 43

Tarassothrips akritus Mound \& Palmer, 1983: 61

Zeugmatothrips bennetti Mound \& Palmer, 1986: 586

PHLAEOTHRIPIDAE-PHLAEOTHRIPINAE

Adraneothrips acutulus Mound \& Marullo, 1996: 252 
Adraneothrips alajuela Mound \& Marullo, 1996: 253 Adraneothrips biadenes Mound \& Marullo, 1996: 255 Adrothrips acanthus Mound, 1970c: 446

Adrothrips cotteri Mound, 1970c: 444

Adrothrips systenus Mound, 1970c: 451

Adurothrips atopus Mound, 1994; 24

Advenathrips inquilinus Morris, Mound \& Schwarz, 2000: 56

Akainothrips asketus Crespi, Morris \& Mound, 2004: 126 Akainothrips bipictus Crespi, Morris \& Mound, 2004: 126 Akainothrips calcica Crespi, Morris \& Mound, 2004: 127 Akainothrips carnei Crespi, Morris \& Mound, 2004: 127 Akainothrips ciliatus Crespi, Morris \& Mound, 2004: 128 Akainothrips crambus Crespi, Morris \& Mound, 2004: 129 Akainothrips dalbyensis Crespi, Morris \& Mound, 2004: 130 Akainothrips dubitalis Crespi, Morris \& Mound, 2004: 130 Akainothrips exourus Crespi, Morris \& Mound, 2004: 131 Akainothrips festus Crespi, Morris \& Mound, 2004: 132 Akainothrips galeus Crespi, Morris \& Mound, 2004: 132 Akainothrips gremius Crespi, Morris \& Mound, 2004: 133 Akainothrips inionis Crespi, Morris \& Mound, 2004: 134 Akainothrips ireneae Crespi, Morris \& Mound, 2004: 135 Akainothrips iskae Crespi, Morris \& Mound, 2004: 135 Akainothrips juliae Crespi, Morris \& Mound, 2004: 136 Akainothrips magnetis Crespi, Morris \& Mound, 2004: 137 Akainothrips monaro Crespi, Morris \& Mound, 2004: 137 Akainothrips notius Crespi, Morris \& Mound, 2004: 138 Akainothrips nyngani Crespi, Morris \& Mound, 2004: 138 Akainothrips ochromelus Crespi, Morris \& Mound, 2004: 139

Akainothrips papyris Crespi, Morris \& Mound, 2004: 140 Akainothrips peronatus Crespi, Morris \& Mound, 2004: 141 Akainothrips polysetulus Crespi, Morris \& Mound, 2004: 141

Akainothrips quintarius Crespi, Morris \& Mound, 2004: 142 Akainothrips roxbyi Crespi, Morris \& Mound, 2004: 142 Akainothrips shirleyi Crespi, Morris \& Mound, 2004: 143 Akainothrips tathrae Crespi, Morris \& Mound, 2004: 143 Akainothrips tessarus Crespi, Morris \& Mound, 2004: 144 Akainothrips tosofagi Crespi, Morris \& Mound, 2004: 144 Akainothrips uncus Crespi, Morris \& Mound, 2004: 145 Akthethrips strobus Mound, 1970c: 452

Andrethrips floydi Mound, 1974a: 111

Apelaunothrips leios Mound, 1970d: 94

Apelaunothrips tasmani Mound, 1974b: 18

Apostlethrips apostus Mound \& Minaei, 2006: 4

Apostlethrips pygus Mound \& Minaei, 2006: 6

Apterygothrips kohai Mound \& Walker, 1986: 42

Apterygothrips sparsus Mound \& Walker, 1986: 43

Apterygothrips viretum Mound \& Walker, 1986: 44

Brakothrips bullus Crespi, Morris \& Mound, 2004: 147

Brakothrips gillesi Crespi, Morris \& Mound, 2004: 147

Brakothrips maafi Crespi, Morris \& Mound, 2004: 148

Brakothrips meandarra Crespi, Morris \& Mound, 2004: 148

Brakothrips pilbara Crespi, Morris \& Mound, 2004: 149

Brakothrips sculptilis Crespi, Morris \& Mound, 2004: 149

Brakothrips stenos Crespi, Morris \& Mound, 2004: 150

Carcinothrips tania Mound \& Morris, 1999: 13

Cartomothrips laughlini Mound \& Walker, 1982d: 309

Cartomothrips neboissi Mound \& Walker, 1982d: 311

Choleothrips percnus Mound, 1971d: 88
Corroboreethrips kallus Mound \& Moritz, 2000: 712

Corroboreethrips siagonus Mound \& Moritz, 2000: 712

Corroboreethrips stomius Mound \& Moritz, 2000: 713

Corroboreethrips subsolanus Mound \& Moritz, 2000: 714

Corroboreethrips suspectus Mound \& Moritz, 2000: 714

Corroboreethrips zophus Mound \& Moritz, 2000: 715 [=suspectus Mound \& Moritz]

Crespithrips enigmaticus Mound \& Morris, 2000: 133

Crespithrips hesperus Mound \& Morris, 2000: 134

Crinitothrips murphyi Mound \& Marullo, 1997: 198

Crinitothrips roomi Mound \& Marullo, 1997: 195

Csirothrips watsoni Mound, 1971a: 399

Dactylothrips aenictus Crespi, Morris \& Mound, 2004: 162

Dactylothrips ascius Crespi, Morris \& Mound, 2004: 163

Dactylothrips atherodes Crespi, Morris \& Mound, 2004: 163

Dactylothrips augusta Crespi, Morris \& Mound, 2004: 164

Dactylothrips boidion Crespi, Morris \& Mound, 2004: 165

Dactylothrips bos Crespi, Morris \& Mound, 2004: 165

Dactylothrips chaitis Crespi, Morris \& Mound, 2004: 167

Dactylothrips dactylis Crespi, Morris \& Mound, 2004: 167

Dactylothrips dens Crespi, Morris \& Mound, 2004: 168

Dactylothrips digitulus Crespi, Morris \& Mound, 2004: 168

Dactylothrips distichus Crespi, Morris \& Mound, 2004: 169

Dactylothrips duplicatus Crespi, Morris \& Mound, 2004: 170

Dactylothrips fragosus Crespi, Morris \& Mound, 2004: 170

Dactylothrips giraulti Mound, 1969b: 177

Dactylothrips junix Crespi, Morris \& Mound, 2004: 171

Dactylothrips kosmos Crespi, Morris \& Mound, 2004: 173

Dactylothrips marsupium Mound, 1969b: 175

Dactylothrips papyricola Crespi, Morris \& Mound, 2004: 174

Dactylothrips phascolus Crespi, Morris \& Mound, 2004: 175

Dactylothrips phoxus Crespi, Morris \& Mound, 2004: 175

Dactylothrips precarius Crespi, Morris \& Mound, 2004: 176

Dactylothrips racemus Crespi, Morris \& Mound, 2004: 178

Dactylothrips rectus Crespi, Morris \& Mound, 2004: 178

Dactylothrips skolops Crespi, Morris \& Mound, 2004: 179

Dactylothrips taediosus Crespi, Morris \& Mound, 2004: 179

Dactylothrips tasmani Mound, 1969b: 179

Dactylothrips turba Crespi, Morris \& Mound, 2004: 180

Dactylothrips vescus Crespi, Morris \& Mound, 2004: 180

Dactylothrips yalgoo Crespi, Morris \& Mound, 2004: 181

Deplorothrips bassus Mound \& Walker, 1986: 49

Domatiathrips cunninghamii Mound, 1993c: 424

Domeothrips aruena Crespi, Morris \& Mound, 2004: 182

Domeothrips catenulatae Crespi, Morris \& Mound, 2004: 183

Domeothrips newmani Crespi, Morris \& Mound, 2004: 184

Domeothrips ophthalmia Crespi, Morris \& Mound, 2004: 185

Dunatothrips aneurae Mound, 1969b: 181

Dunatothrips aulidis Mound \& Morris, 2001: 411

Dunatothrips chapmani Mound \& Morris, 2001: 412

Dunatothrips gloius Crespi, Morris \& Mound, 2004: 189

Dunatothrips skene Mound \& Morris, 2001: 412

Dunatothrips vestitor Mound \& Morris, 2001: 413

Ecacanthothrips andrei Palmer \& Mound, 1978: 158

Glaridothrips koptus Crespi, Morris \& Mound, 2004: 192

Godoythrips asketus Mound \& Marullo, 1996: 275

Gomphiothrips mercedes Mound \& Marullo, 1996: 276 
Grypothrips cambagei Crespi, Morris \& Mound, 2004: 194 Grypothrips darlingi Crespi, Morris \& Mound, 2004: 196 Grypothrips okrius Crespi, Morris \& Mound, 2004: 197 Grypothrips papyrocarpae Crespi, Morris \& Mound, 2004: 197

Hansonthrips drymus Mound \& Marullo, 1996: 280

Hansonthrips selvae Mound \& Marullo, 1996: 281

Haplothrips acacia Mound \& Minaei, 2007: 2944

Haplothrips angusi Mound \& Minaei, 2007: 2946

Haplothrips avius Mound \& Minaei, 2007: 2946

Haplothrips bellisi Mound \& Minaei, 2007: 2947

Haplothrips collyerae Mound \& Walker, 1986: 40

Haplothrips dicksoniae Mound \& Minaei, 2007: 2950

Haplothrips fici Mound \& Minaei, 2007: 2952

Haplothrips gahniae Mound \& Minaei, 2007: 2953

Haplothrips haideeae Mound \& Minaei, 2007: 2956

Haplothrips howei Mound \& Minaei, 2007: 2957

Haplothrips lyndi Mound \& Minaei, 2007: 2959

Haplothrips (Trybomiella) driesseni Mound \& Minaei, 2007: 2951

Haplothrips (Trybomiella) gomphrenae Mound \& Minaei, 2007: 2954

Haplothrips (Trybomiella) heliotropica Mound \& Zapater, 2003: 438

Haplothrips(Trybomiella) ordi Mound \& Minaei, 2007: 2960

Haplothrips(Trybomiella) salicorniae Mound \& Walker, 1986: 54

Haplothrips(Trybomiella) timori Mound \& Minaei, 2007: 2962

Heligmothrips eiletus Mound, 1970c: 458

Heligmothrips frickeri Mound, 1970c: 460

Heptadikothrips thallus Crespi, Morris \& Mound, 2004: 198

Hexadikothrips dalbyi Crespi, Morris \& Mound, 2004: 199

Hindsiothrips navarrensis Goldarazena \& Mound, 1998: 319

Holopothrips carolinae Mound \& Marullo, 1996: 295

Holopothrips mariae Mound \& Marullo, 1996: 298

Holopothrips paulus Mound \& Marullo, 1996: 299

Holopothrips porrosati Mound \& Marullo, 1996: 301

Holopothrips stannardi Mound \& Marullo, 1996: 302

Holopothrips tillandsiae Mound \& Marullo, 1996: 303

Holothrips adelos Mound, 1968c: 146

Holothrips australis Mound, 1974b: 12

Hoplandrothrips choritus Mound \& Walker, 1986: 56

Hoplandrothrips ingenuus Mound \& Walker, 1986: 57

Hoplandrothrips vernus Mound \& Walker, 1986: 57

Hoplothrips anobii Mound \& Walker, 1986: 59

Hoplothrips kea Mound \& Walker, 1986: 60

Hoplothrips oudeus Mound \& Walker, 1986: 62

Iotatubothrips crozieri Mound \& Crespi, 1992: 401

Iotatubothrips kranzae Mound, Crespi \& Tucker, 1998: 11

Jacotia glyptus Mound, 1995b: 91

Jacotia idaeus Mound, 1995b: 93

Jacotia palmerae Mound, 1995b: 93

Jacotia rhodorcha Mound \& Minaei, 2006: 11

Katothrips argenteus Crespi, Morris \& Mound, 2004: 202

Katothrips biconus Crespi, Morris \& Mound, 2004: 203

Katothrips brigalowi Crespi, Morris \& Mound, 2004: 205

Katothrips duplex Mound, 1971a: 413 [=brunneicorpus Girault]

Katothrips capitatus Crespi, Morris \& Mound, 2004: 206
Katothrips dampieri Crespi, Morris \& Mound, 2004: 207

Katothrips diamantinus Crespi, Morris \& Mound, 2004: 207

Katothrips echinatus Crespi, Morris \& Mound, 2004: 208

Katothrips enochrus Crespi, Morris \& Mound, 2004: 209

Katothrips flindersi Crespi, Morris \& Mound, 2004: 210

Katothrips glandis Crespi, Morris \& Mound, 2004: 210

Katothrips grasbyi Crespi, Morris \& Mound, 2004: 211

Katothrips hamersleyi Crespi, Morris \& Mound, 2004: 211

Katothrips hoarei Crespi, Morris \& Mound, 2004: 212

Katothrips hyrum Mound, 1971a: 414

Katothrips mackeyanae Crespi, Morris \& Mound, 2004: 213

Katothrips maslini Crespi, Morris \& Mound, 2004: 213

Katothrips melasmus Crespi, Morris \& Mound, 2004: 214

Katothrips mitchelli Crespi, Morris \& Mound, 2004: 215

Katothrips neottus Crespi, Morris \& Mound, 2004: 216

Katothrips nodus Crespi, Morris \& Mound, 2004: 216

Katothrips orionis Crespi, Morris \& Mound, 2004: 217

Katothrips papulus Crespi, Morris \& Mound, 2004: 217

Katothrips pendulae Mound, 1971a: 414

Katothrips patus Crespi, Morris \& Mound, 2004: 219

Katothrips sifrus Crespi, Morris \& Mound, 2004: 220

Katothrips spinosissimus Crespi, Morris \& Mound, 2004: 221

Katothrips spinosus Crespi, Morris \& Mound, 2004: 221

Katothrips stuarti Crespi, Morris \& Mound, 2004: 222

Katothrips tagacis Crespi, Morris \& Mound, 2004: 223

Katothrips uniconus Crespi, Morris \& Mound, 2004: 225

Katothrips unicus Crespi, Morris \& Mound, 2004: 225

Katothrips yamma Mound, 1971a: 416

Kellyia bagnalli Crespi, Morris \& Mound, 2004: 228

Kellyia biadenes Mound, 1971a: 418

Kellyia froggatti Crespi, Morris \& Mound, 2004: 229

Kellyia giraulti Crespi, Morris \& Mound, 2004: 230

Kellyia karnyi Crespi, Morris \& Mound, 2004: 231

Kellyia moultoni Crespi, Morris \& Mound, 2004: 232

Kellyia palmerae Crespi, Morris \& Mound, 2004: 233

Kellyia pitkini Crespi, Morris \& Mound, 2004: 234

Kellyia priesneri Crespi, Morris \& Mound, 2004: 234

Kellyia stannardi Crespi, Morris \& Mound, 2004: 235

Kellyia wilsoni Crespi, Morris \& Mound, 2004: 236

Kladothrips arotrum Mound, 1971a: 447

Kladothrips ellobus Mound, 1971a: 424

Kladothrips habrus Mound, 1971a: 442

Kladothrips hamiltoni Mound \& Crespi, 1995: 148

Kladothrips harpophyllae Mound, Crespi \& Kranz, 1996: 1179

Kladothrips kinchega Wills, Chapman, Mound et. al., 2004: 171

Kladothrips maslini Mound, Crespi \& Kranz, 1996: 1181

Kladothrips morrisi Mound, Crespi \& Kranz, 1996: 1185

Kladothrips nicolsoni Mcleish, Chapman \& Mound, 2006: 561

Kladothrips pilbara Mound, Crespi \& Kranz, 1996: 1194

Kladothrips schwarzi Mound, Crespi \& Kranz, 1996: 1187

Kladothrips sterni Mound, Crespi \& Kranz, 1996: 1189

Kladothrips torus Mound, Crespi \& Kranz, 1996: 1191

Kladothrips waterhousei Mound \& Crespi, 1995: 152

Kladothrips xiphius Mound, Crespi \& Kranz, 1996: 1182

Kladothrips yalgoo Crespi, Morris \& Mound, 2004: 253

Kladothrips zygus Mound, Crespi \& Kranz, 1996: 1196

Klambothrips myopori Mound \& Morris, 2007b: 43 
Koptothrips dyskritus Mound, 1971a: 430

Koptothrips xenus Mound, 1971a: 433

Koptothrips zelus Mound, 1971a: 433

Leeuwenia diospyri Mound, 2004b: 34

Leeuwenia polyosmae Mound, 2004b: 35

Leeuwenia scolopiae Mound, 2004b: 36

Leeuwenia tetrastigmae Mound, 2004b: 36

Lichanothrips albus Mound, 1971a: 437

Lichanothrips calcis Crespi, Morris \& Mound, 2004: 260

Lichanothrips curvatus Crespi, Morris \& Mound, 2004: 261

Lichanothrips magnificus Mound, 1971a: 437

Lichanothrips metopus Crespi, Morris \& Mound, 2004: 262

Lichanothrips pastinus Crespi, Morris \& Mound, 2004: 263

Lichanothrips triquetrus Crespi, Morris \& Mound, 2004: 266

Lichanothrips xouthus Crespi, Morris \& Mound, 2004: 266

Liothrips neosmerinthi Mound \& Palmer, 1992: 332

Liothrips tractabilis Mound \& Pereyra, 2008: 64

Lissothrips clayae Mound, 1989: 8

Lissothrips dentatus Mound \& Walker, 1986: 66

Lissothrips dugdalei Mound \& Walker, 1986: 67

Lissothrips gersoni Mound \& Walker, 1986: 68

Lissothrips okajimai Mound, 1989: 9

Litotetothrips shoreae Mound, 1983c: 14

Macrophthalmothrips heinzei Mound, 1972c: 85

Macrophthalmothrips kiesteri Mound, 1987: 281

Majerthrips barrowi Mound \& Minaei, 2006: 8

Malacothrips curepe Mound \& Marullo, 1996: 331

Malacothrips tunapuna Mound \& Marullo, 1996: 333

Maxillata tremblayi Mound \& Marullo, 1996: 335

Mixothrips nakaharai Mound \& Marullo, 1996: 339

Murphythrips legalis Mound \& Palmer, 1983: 422

Mystrothrips dilatus Mound, 1970d: 100

Neohoodiella jennibeardae Mound \& Williams, 2002: 18

Ostlingothrips corini Crespi, Morris \& Mound, 2004: 267

Ostlingothrips pastus Crespi, Morris \& Mound, 2004: 267

Paracholeothrips calcicolae Crespi, Morris \& Mound, 2004: 270

Paracholeothrips gracilis Crespi, Morris \& Mound, 2004: 272

Paracholeothrips mulgae Crespi, Morris \& Mound, 2004: 273

Phallothrips houstoni Mound \& Crespi, 1992: 403

Podothrips anomalus Mound \& Minaei, 2007: 2967

Podothrips ardis Mound \& Minaei, 2007: 2969

Podothrips barrowi Mound \& Minaei, 2007: 2970

Podothrips orarius Mound \& Walker, 1986: 71

Podothrips regina Mound \& Minaei, 2007: 2971

Podothrips ritchiei Mound \& Minaei, 2007: 2972

Podothrips turangi Mound \& Walker, 1986: 72

Podothrips websteri Mound \& Minaei, 2007: 2972

Priesneria peronis Mound \& Minaei, 2007: 2974

Pristothrips pollostus Mound \& Marullo, 1996: 349

Psalidothrips grandis Mound, 1970d: 103

Psalidothrips minor Mound, 1970d: 103

Psalidothrips moeone Mound \& Walker, 1986: 74

Psalidothrips tane Mound \& Walker, 1986: 75

Psalidothrips taylori Mound \& Walker, 1986: 76

Pseudophilothrips didymopanicis Del-Claro \& Mound, 1995: 194
Pseudophilothrips gandolfi Mound, Wheeler \& Williams, 2010: 62

Rhopalothripoides colus Crespi, Morris \& Mound, 2004: 276

Rhopalothripoides disbamatus Crespi, Morris \& Mound, 2004: 276

Rhopalothripoides luteus Crespi, Morris \& Mound, 2004: 277

Rhopalothripoides pickardii Crespi, Morris \& Mound, 2004: 278

Rhopalothripoides victoriae Crespi, Morris \& Mound, 2004: 279

Sacothrips catheter Mound, 1971d: 94

Sacothrips corycidis Mound, 1971d: 94

Sacothrips galbus Mound, 1971d: 95

Sacothrips ingens Mound, 1971d: 95

Sacothrips milvus Mound, 1971d: 96

Sartrithrips areius Crespi, Morris \& Mound, 2004: 281

Sartrithrips bapto Mound \& Morris, 2001: 415

Sartrithrips luctator Mound \& Morris, 2001: 415

Sartrithrips mars Mound \& Morris, 2001: 416

Sartrithrips popinator Mound \& Morris, 2001: 416

Sartrithrips pyctus Mound \& Morris, 2001: 417

Sartrithrips vesper Mound \& Morris, 2001: 417

Schwarzithrips glyphis Mound \& Morris, 2000: 135

Schwarzithrips zammit Mound \& Morris, 2000: 135

Senithrips psomus Mound \& Minaei, 2006: 10

Solomonthrips fimbrii Mound, 1970d: 110

Solomonthrips greensladei Mound, 1970d: 107

Solomonthrips intermedius Mound, 1970d: 110

Solomonthrips setifer Mound, 1970d: 111

Solomonthrips striatus Mound, 1970d: 113

Sophikothrips malaitae Mound, 1970d: 114

Sophiothrips aleurodisci Mound \& Walker, 1982a: 349

Sophiothrips boltoni Mound, 1977c: 178

Sophiothrips duvali Mound \& Walker, 1982a: 352

Sophiothrips greensladei Mound \& Walker, 1982a: 352

Sophiothrips kibbyi Mound, 1977c: 179

Stephanothrips barretti Mound, 1972d: 100

Stephanothrips ferrari Mound, 1972d: 100

Stigmothrips antennatus Mound, 1970d: 93

Stigmothrips coloratus Mound, 1970d: 91

Stomothrips mouldeni Mound \& Minaei, 2006: 14

Streptothrips tribulatius Mound \& Minaei, 2006: 15

Suocerathrips linguis Mound \& Marullo, 1994: 96

Tolmetothrips granti Mound, 1970d: 114

Triadothrips arckaringa Crespi, Morris \& Mound, 2004: 290

Triadothrips briga Crespi, Morris \& Mound, 2004: 290

Triadothrips hesmus Crespi, Morris \& Mound, 2004: 290

Truncatothrips terryae Crespi, Morris \& Mound, 2004: 291

Turmathrips apistus Crespi, Morris \& Mound, 2004: 294

Turmathrips dypistus Crespi, Morris \& Mound, 2004: 294

Vicinothrips bullatus Mound \& Morris, 2000: 136

Walkerthrips neatus Mound \& Walker, 1986: 45

Warithrips aridum Crespi, Morris \& Mound, 2004: 297

Warithrips maelzeri Mound, 1971a: 456

Warithrips polydens Crespi, Morris \& Mound, 2004: 299

Warithrips polysensori Crespi, Morris \& Mound, 2004: 299

Williamsiella jacoti Mound, 1977c: 184

Williamsiella johanseni Mound, 1977c: 184 
Williamsiella tambopata Mound, 1989: 14

Williamsiella zaps Mound, 1989: 15

Xaniothrips eremus Mound \& Morris, 1999: 183

Xaniothrips foederatus Mound \& Morris, 1999: 184

Xaniothrips leukandrus Mound, 1971a: 461

Xaniothrips mulga Mound \& Morris, 1999: 186

Xaniothrips rhodopus Mound \& Morris, 1999: 186

Xaniothrips xantes Mound, 1971: 459
Xaniothrips zophus Mound \& Morris, 2000: 187

Yarnkothrips kolourus Mound \& Walker, 1986: 83

Zemiathrips anatolis Mound, 2002d: 212

Zemiathrips biseta Mound, 2002d: 212

Zemiathrips greensladeae Mound, 2002d: 213

Zemiathrips triseta Mound, 2002d: 214

Zemiathrips uptoni Mound, 2002d: 214

To this end, international collaborative research efforts with colleagues allowed Laurence to reach non-English speaking scientists by producing publications on thrips in Chinese (Wang \& Mound 1996), Spanish (Maes \& Mound 1993; Mound et al. 1994; Mound \& Isaza 1994; Goldarazena \& Mound 1997), Italian (Marullo and Mound 1995), Portuguese (Monteiro et al. 1995), and German (Tschuh et al., 2006).

Mound and Teulon (1995) developed the concept of Thysanoptera as phytophagous opportunists; that is, their ability to exploit transient and ephemeral environments and the resources they hold. The habits and life-history strategies of thrips were put into an evolutionary perspective. Mound (1997) further explored the evolutionary radiation of the Thysanoptera and their systematic and biological diversity, including numbers of species and feeding associations. Both Mound \& Teulon (1995) and Mound (1997) helped develop a basis for the modern-day research into the ecology and invasion biology of thrips (Morse \& Hoddle 2006). Mound (2005b) pointed out that established views of the role of density-dependent factors on thrips populations were deeply flawed (Andrewartha \& Birch 1954), but that research on the importance of natural enemies recently had led to the development of ecologically based, sustainable management approaches for dealing with pest species (e.g. Funderburk et al. 2000).

Mound (2005b) observed that transfer between plant hosts for polyphagous thrips species was sometimes asymmetric, that polyphagous species sometimes produce localized strains feeding on a particular plant species, and that apparently monophagous species sometimes have different host associations in different parts of their geographic ranges. Morphology had proved limited in resolving issues of strains and cryptic species that were indicated by such differences in behavior and biology. Crespi et al. (2004) embraced the potentialities of molecular research to resolve questions in taxonomy, but urged taking a judicial consensus of both morphological and molecular data, and producing hypotheses of identity and group membership that can be tested with additional data. Mound and Morris (2007a) emphasized that a phylogenetic (i.e. systematic) classification that incorporates predictions concerning evolutionary relationships that are important in biological studies. The available phenetic systems for Thysanoptera stress the importance of differences that serve no broader purpose in biology; they noted that some groups of taxa are well resolved with recent molecular data, but the deeper relationships within the Thysanoptera remain unclear. To that end, Hoddle et al. (2008a) used molecular and morphological data to examine the relationships between species of Scirtothrips, and Hoddle et al. (2008c) used molecular techniques to demonstrate the synonomy of Scirtothrips species described from avocados (Persea americana) in Mexico and to develop a molecular key to identify these species (Rugman-Jones et al. 2006). Mound et al. (2010b) resolved cryptic species in the genus Pseudophilothrips using morphology and DNA. This unique combination of using morphology and genetics to unravel seemingly intractable problems in thrips studies has thrown wide open the doors to addressing not only questions pertaining to curious ecological questions, but is also of immense importance in tackling the difficult problems associated with pest identifications, especially border interceptions that require rapid and accurate identity determinations - a fact recently illustrated by the realization that the Western Flower Thrips, Frankliniella occidentalis, is actually a complex of two morphologically inseparable species (Rugman-Jones et al. 2010).

Laurence Mound lives in Canberra (Fig. 11), where he works at CSIRO in his custom-designed office/lab, with his back facing the door. His slide collection is kept in custom-built cabinets outside of the office. Exclamations of "fiddle-sticks" may erupt occasionally as he works in Photoshop, or looks at poorly mounted thrips! Conversations in the lab about thrips are intense and probing. Laurence is soft-spoken so discussions are typically quiet, but often punctuated by a knee slap, hand clap, a giggling outburst, or cupped hands held to the cheeks or mouth. Trips to the field are characterized by the donning of a broad brimmed sunhat and long-sleeved shirt, the wearing of a cheap backpack holding the classic white Aussie BBQ tray for catching thrips beaten from foliage with a stainless steel garden trowel, an old hanky for wiping the tray clean, plastic centrifuge vials with $95 \%$ ethanol, the note book with rip-out labels for the vials, and the fine paint brush lodged behind one ear. The scenery, collecting, and conversa- 
tions on these trips are always memorable. A home-prepared lunch is taken daily at the Botanic Gardens next to CSIRO, and this is a great opportunity to admire and learn about the amazing plant diversity of Australia and the extensive bird life. Laurence has produced and maintains websites on identification and resources of the Thysanoptera (Mound 2009b) as well as the extremely important and highly useful world catalogue of the Thysanoptera (Mound 2008b). Together with Desley Tree he is producing an ambitious Lucid identification and information system to the thrips of Australia, and a parallel system to the thrips of New Zealand is also in preparation. He considers taxonomy an integral part of biology, and he continues in his commitment to weave information across disciplines on sociality, ecology, and host relationships into the species that are recognized. He finds taxonomy a demanding and frustrating, yet deeply satisfying, pursuit. Laurence Mound continues to look forward, and has accurately identified the greatest challenge facing all of us - the recruitment and training of the next generation of thysanopterologists. We need to be investing in this talent now, so that the forward global momentum that the discipline is enjoying, owed in large part to Laurence's efforts, does not wane.

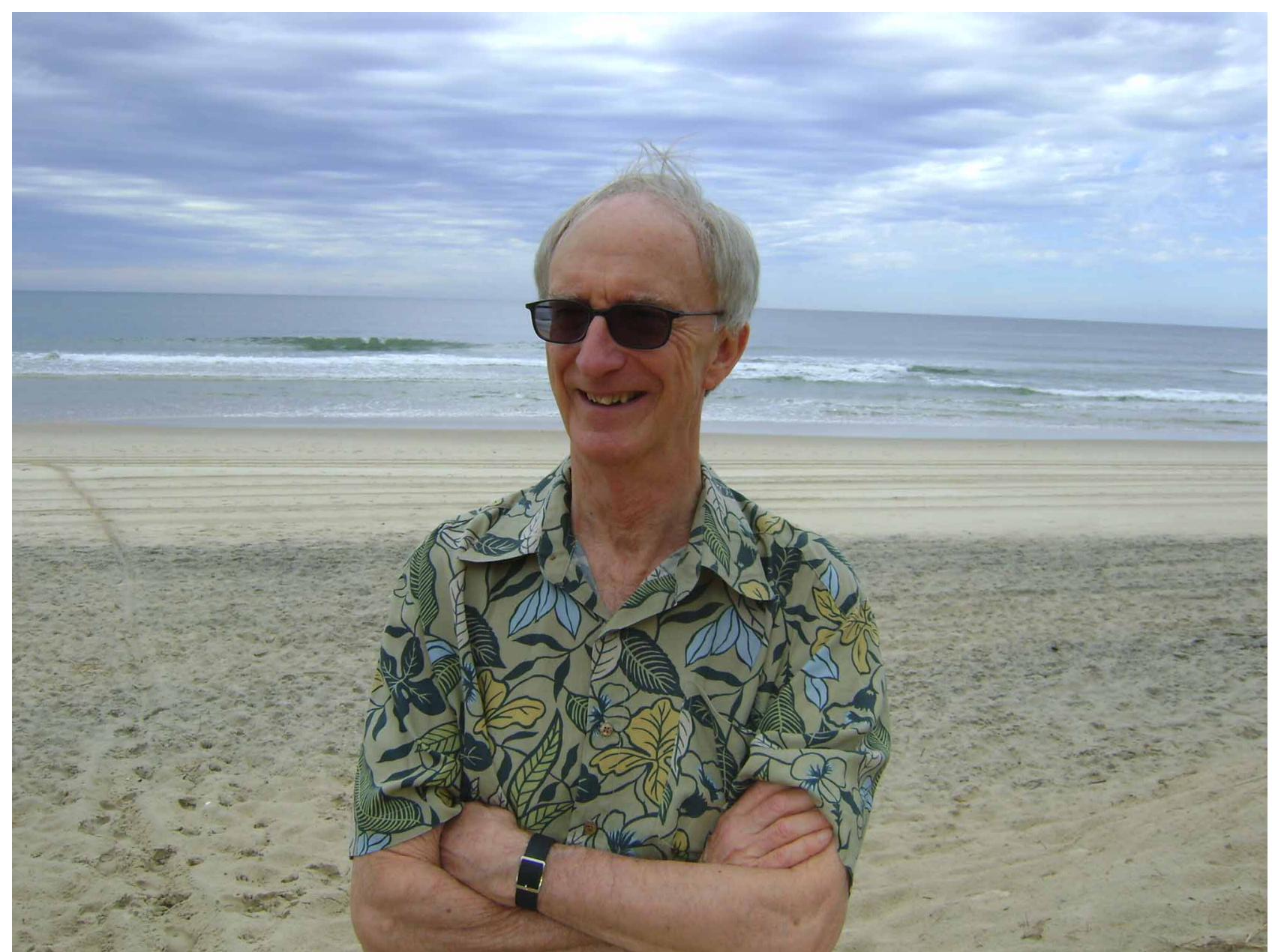

FIGURE 11. Laurence Mound at 76 years of age. (Photo by Kambiz Minaei).

\section{Acknowledgements}

The authors thank Gerald Moritz (Institute of Zoology, University of Halle, Germany) for providing information about Laurence Mound. Gillian Watson (Department of Food and Agriculture, State of California, Sacramento, USA) provided first-hand information about Laurence Mound and the Natural History Museum, London. This review was solicited by the Chief Editor of Zootaxa. We thank Alice Wells (Fauna Section, Australian Biological Resources Study, Canberra, Australia) for recommending us as authors and for providing information and invaluable advice. 


\section{References}

Andrewartha, H.G. \& Birch, L.C. (1954) The Distribution and Abundance of Animals. The University of Chicago Press, Chicago and London.

Bhatti, J.S. \& Mound, L.A. (1980) The genera of grass and cereal-feeding Thysanoptera related to the genus Thrips (Thysanoptera: Thripidae). Bulletin of Entomology, 21, 1-22.

Bhatti, J.S. \& Mound, L.A. (1992) A new genus of thripine Thysanoptera-Terebrantia with craspedote terga, from Trinidad. Zoology (Journal of Pure and Applied Zoology) 3, 173-188.

Bhatti, J.S. \& Mound, L.A. (1994) A new genus of Terebrantian Thysanoptera from New Guinea, related to Foliothrips and Cestrothrips (Thripidae). Zoology (Journal of Pure and Applied Zoology), 4, 161-176.

Bink-Moenen, R.M. \& Mound, L.A. (1990) Whiteflies: diversity, biosystematics, and evolutionary pattern. In: Gerling, D. (ed.) Whiteflies: Their Bionomics, Pest Status, and Management, Intercept LTD, Andover, UK, pp. 1-11.

Brothers, D.J. \& Mound, L.A. (1985) Eugynothrips Priesner, 1926 (Insecta, Thysanoptera): proposed designation of Cryptothrips conocephali Kamy, 1963 as type species. Bulletin of Zoological Nomenclature, 42, 382-4.

Crespi, B.J. (1992a) Behavioural ecology of Australian gall thrips (Insecta: Thysanoptera). Journal of Natural History, 26, 769-809.

Crespi, B.J. (1992b) Eusociality in Australian gall thrips. Nature, 359, 724-726.

Crespi, B.J., Morris, D.C. \& Mound, L.A. (2004) Evolution of Ecological and Behavioural Diversity: Australian Acacia Thrips as Model Organisms. Australian Biological Resources Study \& Australian National Insect Collection. Canberra, Australia.

Darwin, C. (1937) The Voyage of the Beagle. P. F. Collier and Son Corporation, New York.

Del-Claro, K. \& Mound, L.A. (1996) Phenology and description of a new species of Liothrips (Thysanoptera; Phlaeothripidae) from Didymopanax (Araliaceae) in Brazilian cerrado. Revista de Biologia Tropical, 44, 193-197.

Diffie, S., Edwards, G.B. \& Mound, L.A. (2008) Thysanoptera of Southeastern U.S.A.: a checklist for Florida and Georgia. Zootaxa, 178, 45-62.

Ferris, T. (2010) The Science of Liberty Democracy, Reason, and the Laws of Nature. Harper Collins Publishers, New York.

Fortey, R. (2008) Dry Storeroom No. 1- The Secret Life of the Natural History Museum. Alfred A.Knopf, New York.

Funderburk, J., Stavisky, J. \& Olson, S. (2000) Predation of Frankliniella occidentalis (Thysanoptera: Thripidae) in field pepper by Orius insidiosus (Hemiptera: Anthocoridae). Environmental Entomology, 29, 376-382.

Funderburk, J., Mound, L. \& Sharma, J. (2008) Thysanoptera inhabiting native terrestrial orchids in northern Florida and southern Georgia. Journal of Entomological Science, 42, 573-581.

Gaston, K.J. \& Mound, L.A. (1993) Taxonomy, hypothesis-testing and the biodiversity crisis. Proceedings of the Royal Society, London, B, 251, 139-142.

Gillespie, P.S, Mound, L.A. \& Wang, C.L. (2002) Austro-oriental genus Parabaliothrips Priesner (Thysanoptera, Thripidae) with a new Australian species forming male aggregations. Australian Journal of Entomology, 41, 111-117.

Goldarazena, A. \& Mound, L.A. (1997) Introducción a la fauna de los tisanópteros (Cl. Insecta; O. Thysanoptera) de NavarraNafarroa, sus plantas hospedadoras y su distribución. I Suborden Terebrantia. Estudios del Museo de Ciencias Naturales de Alava, 12, 167-202.

Goldarazena, A. \& Mound, L.A. (1998) Hindsiothrips navarrensis sp. n. (Thysanoptera; Phlaeothripidae) from Spain, with the first record of Tylothrips osborni (Hinds) from Europe. Entomologists Monthly Magazine, 134, 319-324.

Goldarazena, A. \& Mound, L.A. (2006) The biodiversity of Thysanoptera at the Great Smoky Mountains National Park (USA); an introduction. Boletin Sociedad Entomologica Aragonesa, 38, 291-299.

Goldarazena, A. \& Mound, L.A. (2010) A new species of Charassothrips Hood from Colombia (Insecta, Thysanoptera, Thripidae), with an updated key to the known species. Journal of Insect Science, 10, 70.

Green, K. \& Mound, L.A. (1994) An extension to the insect fauna of Heard Island. Polar Record, 30, 131-132.

Hamilton, W.D. (1967) Extraordinary sex ratios. Science, 156 (3774), 477-488.

Hoddle, M.S. \& Mound, L.A. (2003) The genus Scirtothrips in Australia (Insecta, Thysanoptera, Thripidae). Zootaxa, 268, 140.

Hoddle, M.S. \& Mound, L.A. (2011) Thysanoptera of the Galápagos Islands. Pacific Science, 65(4), in press.

Hoddle, M.S., Mound, L.A. \& Nakahara, S. (2004) Thysanoptera recorded from California, USA: a checklist. Florida Entomologist, 87, 317-323.

Hoddle, M.S., Stosic, C.D. \& Mound, L.A. (2006) Populations of North American bean thrips, Caliothrips fasciatus (Pergande) (Thysanoptera: Thripidae: Panchaetothripinae) not detected in Australia. Australian Journal of Entomology, 45, $122-129$.

Hoddle, M.S., Heraty, J.M., Rugman-Jones, P.F., Mound, L.A. \& Stouthamer, R. (2008a) Relationships among species of Scirtothrips (Thysanoptera: Thripidae, Thripinae) using molecular and morphological data. Annals of the Entomological Society of America, 101, 491-500.

Hoddle, M.S., Mound, L.A. \& Paris, D. (2008b) Thrips of California. CD-ROM published by CBIT, Brisbane (http:// www.lucidcentral.org/keys/v3/thrips_of_california.html).

Hoddle, M.S., Mound, L.A., Rugman-Jones, P.F. \& Stouthamer, R. (2008c) Synonomy of five Scirtothrips species (Thysanoptera: Thripidae) described from avocados (Persea americana) in Mexico. Florida Entomologist, 91, 16-21.

Hoddle, M.S., Hoddle, C.D. \& Mound, L.A. (2008d) An inventory of Thysanoptera collected from French Polynesia. Pacific Science, 62, 509-515. 
Houston, K.J., Mound, L.A. \& Palmer, J.M. (1991) Two pest thrips (Thysanoptera) new to Australia, with notes on the distribution and structural variation of other species. Journal of the Australian Entomological Society, 30, $231-232$.

Maes, J.-M. \& Mound L.A. (1993) Catalogo de los Aleyrodidae (Homoptera) de Nicaragua. Revista Nicaragua Entomologia, $25,37-49$.

Marullo, R. \& Mound, L.A. (1995) Su una classificazione sopra-generica della famiglia Aeolothripidae (Thysanoptera). Atti del XVII Congresso Nazionale Italiano di Entomologia, Udine, 87-90.

Marullo, R. \& Mound, L.A. (1997) A second species of the genus Australothrips (Thysanoptera). Australian Journal of Entomology, 36, 221-224.

Marullo, R. \& Mound, L.A. (2001) Nexothrips; a new genus of thripine Thysanoptera (Insecta) from the neotropics, and its palaeotropical faunal affinities. Journal of the New York Entomological Society, 108, 231-236.

McLeish, M.J., Chapman, T.W. \& Mound, L.A. (2006) Gall morpho-type corresponds to separate species of gall-inducing thrips (Thysanoptera: Phlaeothripidae). Biological Journal of the Linnean Society, 88, 555-563.

Minaei, K. \& Mound, L.A. (2008) The Thysanoptera Haplothripini (Phlaeothripinae) of Iran. Journal of Natural History, 42, 2617-2658.

Monteiro, R.C., Zucchi, R.A. \& Mound, L.A. (1995) Frankliniella occidentalis (Pergande, 1895) (Thysanoptera, Thripidae) em Chrysanthemum sp. Anais do $15^{\circ}$ Congresso Brasileiro de Entomologia, Caxambu: 774.

Moritz, G. \& Mound, L.A. (1996) Common Thysanoptera of Europe. An Electronic Identification System. CAB International, Wallingford, UK. ACIAR \& CSIRO Publishing, Melbourne.

Moritz, G. \& Mound, L.A. (1998) Thysanoptera of Quarantine Importance to Australia. AQIS, CD-ROM.

Moritz, G., Morris, D.C. \& Mound, L.A. (2001) ThripsID - Pest Thrips of the World. An Interactive Identification and Information System. CD-ROM.

Moritz, G., Mound, L.A., Morris, D.C. \& Goldarazena, A. (2004) Pest thrips of the world-visual and molecular identification of pest thrips. CD-ROM published by CBIT, Brisbane (http://www.cbit.uq.au/software/pestthrips/default.htm).

Morris, D.C., Mound, L.A. \& Scwarz, M.P. (2000) Advenathrips inquilinus: a new genus and species of social parasites (Thysanoptera: Phlaeothripidae). Australian Journal of Entomology, 39, 53-57.

Morse, J.G. \& Hoddle, M.S. (2006) Invasion biology of thrips. Annual Review of Entomology, 51, 67-89.

Mound, L.A. (1962a) Studies on the olfaction and colour sensitivity of Bemisia tabaci (Genn.) (Homoptera: Aleyrodidae). Entomologia Experimentalis et Applicata, 5, 99-104.

Mound, L.A. (1962b) A Pyralid moth from ant's nests in Nigeria. Entomologist, 95, 20-21.

Mound, L.A. (1962c) Extra-floral nectaries of cotton and their secretions. Empire Cotton Growing Review, 39, $254-261$.

Mound, L.A. (1963) Host correlated variation in Bemisia tabaci (Gennadius) (Homoptera: Aleyrodidae). Proceedings of the Royal Entomological Society of London (A), 38, 171-180.

Mound, L.A. (1965a) Effect of whitefly on cotton in the Sudan Gezira. Empire Cotton Growing Review, 42, $290-294$.

Mound, L.A. (1965b) An introduction to the Aleyrodidae of western Africa (Homoptera). Bulletin of the British Museum (Natural History) Entomology, 17, 115-160.

Mound, L.A. (1966a) A revision of the British Aleyrodidae (Hemiptera: Homoptera). Bulletin of the British Museum (Natural History) Entomology, 17, 115-160.

Mound, L.A. (1966b) The genus Hercinothrips (Thysanoptera) with one new species. Annals and Magazine of Natural History, $13(8), 243-247$.

Mound, L.A. (1966c) The British species of the genus Taeniothrips (Thysanoptera). Entomologists's Gazette, 17, 55-60.

Mound, L.A. (1967a) A new species of whitefly (Homoptera: Aleyrodidae) from ferns in British greenhouses. Proceedings of the Royal Entomological Society of London (B), 36, 30-32.

Mound, L.A. (1967b) The British species of the genus Thrips (Thysanoptera). Entomologists' Gazette, 17, 55-60.

Mound, L.A. (1967c) A taxonomic revision of the Australian Aeolothripidae (Thysanoptera). Bulletin of the British Museum (Natural History). Entomology, 20, 41-74.

Mound, L.A. (1967d) A new genus and species of Thysanoptera predatory on mites in Iraq. Bulletin of Entomological Research, 57, 315-319.

Mound, L.A. (1968a) New synonymy in the South African genus Synaptothrips Trybom (Thysanoptera) with a key to the species. Journal of the Entomological Society of South Africa, 31, 87-95.

Mound L.A. (1968b) A new species of Scirtothrips from Kenya attacking tea, with synonymic notes on two related pest species. Bulletin of Entomological Research, 57, 333-338.

Mound L.A. (1968c) A review of R.S. Bagnall's Thysanoptera collections. Bulletin of the British Museum (Natural History). Entomology Supplement, 11, 1-181.

Mound, L.A. (1969a) A species of aphid newly recorded in Britain. Entomologist's Monthly Magazine, 105, 62.

Mound, L.A. (1969b) Revision of three Australian genera of Phlaeothripidae (Thysanoptera) with new species, and one new generic synonym. Journal of the Australian Entomological Society, 8, 173-186.

Mound, L.A. (1970a) Intra-gall variation in Brithothrips fuscus Moulton with notes on other Thysanoptera induced galls on Acacia phyllodes in Australia. Entomologist's Monthly Magazine, 105, 159-162.

Mound, L.A. (1970b) Studies on heliothripine Thysanoptera. Proceedings of the Royal Entomological Society of London (B), 3 , 4-56.

Mound, L.A. (1970c) Convoluted maxillary stylets and the systematics of some Phlaeothripine Thysanoptera from Casuarina 
trees in Australia. Australian Journal of Zoology, 18, 439-463.

Mound, L.A. (1970d) Thysanoptera from the Solomon Islands. Bulletin of the British Museum (Natural History). Entomology, 24, 83-126.

Mound, L.A. (1971a) Gall-forming thrips and allied species (Thysanoptera: Phlaeothripinae) from Acacia trees in Australia. Bulletin of the British Museum (Natural History), 25, 387-466.

Mound, L.A. (1971b) A review of the Melanesian genus Mycenothrips (Thysanoptera). Journal of Natural History, 5, $279-283$.

Mound, L.A. (1971c) The feeding apparatus of thrips. Bulletin of Entomological Research, 60, 547-548.

Mound, L.A. (1971d) The complex of Thysanoptera in rolled leaf galls on Geijera. Journal of the Australian Entomological Society, 10, 83-97.

Mound, L.A. (1972a) Further studies on the Australian Aeolothripidae (Thysanoptera). Journal of the Australian Entomological Society, 11, 37-54.

Mound, L.A. (1972b) Polytypic species of spore-feeding Thysanoptera in the genus Allothrips Hood (Phlaeothripidae). Journal of the Australian Entomological Society, 11, 23-36.

Mound, L.A. (1972c) Tropical fungus-feeding thrips in the genus Macrophtalmothrips. Journal of Entomology (B), 41, 77-88.

Mound, L.A. (1972d) Species complexes and the generic classification of leaf-litter thrips of the Tribe Urothripini (Phlaeothripidae). Australian Journal of Zoology, 20, 83-103.

Mound, L.A. (1973) Thrips and whiteflies. In: Gibbs, A.J. (ed.) Viruses and Invertebrates, North Holland Publishing Company, Amsterdam, pp. 229-242.

Mound, L.A. (1974a) The Nesothrips complex of spore-feeding Thysanoptera (Phlaeothripidae: Idolothripinae). Bulletin of the British Museum (Natural History) Entomology, 31, 109-188.

Mound, L.A. (1974b) Spore-feeding thrips (Phlaeothripidae) from leaf litter and dead wood in Australia. Australian Journal of Zoology Supplement, 27, 1-106.

Mound, L.A. (1976a) Thysanoptera of the genus Dichromothrips on Old World Orchidaceae. Biological Journal of the Linnean Society, 8, 245-265.

Mound, L.A. (1976b) The identity of the greenhouse thrips Heliothrips haemorrhoidalis (Bouche) (Thysanoptera) and the taxonomic significance of spanandric males. Bulletin of Entomological Research, 66, 179-180.

Mound, L.A. (1977a) Species diversity and the systematics of some New World leaf-litter Thysanoptera (Phlaeothripinae: Glyptothripini). Systematic Entomology, 2, 225-244.

Mound, L.A. (1977b) A new genus of Aeolothripidae (Thysanoptera) from New Zealand and New Caledonia. New Zealand Journal of Zoology, 4, 149-152.

Mound, L.A. (1977c) Leaf-litter Thysanoptera of the sub-tribe Williamsiellina (Phlaeothripidae). Bulletin of the British Museum (Natural History). Entomology, 36, 171-192.

Mound, L.A. (1978) Five new species of Thripidae (Thysanoptera) endemic to New Zealand. New Zealand Journal of Zoology, 5, 615-622.

Mound, L.A. (1983a) Biology and identity of whitefly vectors of plant pathogens. In: Plumb, R.T, \& Thresh, J.M. (eds.) Plant Virus Epidemiology. Blackwell Publishers, Oxford, pp. 305-313.

Mound, L.A. (1983b) Natural and disrupted patterns of geographical distribution in Thysanoptera (Insecta). Journal of Biogeography, 10, 119-133.

Mound, L.A. (1983c) A new species of Litetothrips (Thysanoptera: Phlaeothripidae) from Shoreya in Melaya. Annals of Entomology, 1, 12-14.

Mound, L.A. (1984) Zoogeographical distribution of whiteflies. Current Topics in Vector Research, 2, $185-197$.

Mound, L.A. (1987) A second sexually dimorphic neotropical species of Macrophthalmothrips (Thysanoptera; Phlaeothripidae). Journal of Natural History, 21, 281-284.

Mound, L.A. (1989) Systematics of thrips (Insecta: Thysanoptera) associated with mosses. Zoological Journal of the Linnean Society, 96, 1-17.

Mound, L.A. (1990) A new genus and species (Thysanoptera) from Western Australia with elongate mouth parts. Entomologist's Monthly Magazine, 126, 213-216.

Mound, L.A. (1991a) The first thrips species (Insecta, Thysanoptera) from cycad male cones, and its family level significance. Journal of Natural History, 25, 647-652.

Mound, L.A. (1991b) Secondary sexual character variation in male Actinothrips species (Insecta: Thysanoptera), and its probable significance in fighting behavior. Journal of Natural History, 25, 933-943.

Mound, L.A. (1992) Why collect? Responsibilities and possibilities in a museum of natural history. Insect Collection News, 7 , $8-14$.

Mound, L.A. (1993a) Thrips - the ideal opportunists. In: Memorias, XX Congreso de la Sociedad Colombiana de Entomologia, pp. 316-321.

Mound, L.A. (1993b) Whitefly evolutionary strategies: host specificity, polyphagy, or biotypes. In: Memorias, XX Congreso de la Sociedad Columbiana de Entomologia, pp. 244-250.

Mound, L.A. (1993c) The first thrips species (Insecta) inhabiting leaf domatia: Domatiathrips cunninghamii gen \& sp n. Journal of the New York Entomological Society, 101, 424-430.

Mound, L.A. (1995a) Homoplasy and the systematics of the Phlaeothripine Thysanoptera, with a short-tubed Australian Urothripine. Courier Forschunginstitut Senckenburg, 178, 21-25. 
Mound, L.A. (1995b) Jacotia (Phlaeothripidae), a second genus of Thysanoptera with disjunct distribution between Australia and South Africa. Journal of the Australian Entomological Society, 34, 90-94.

Mound, L.A. (1996) Thysanoptera. In: Wells, A. (ed.) Zoological Catalogue of Australia. Volume 26. Psocoptera, Phthiraptera, Thysanoptera. CSIRO Entomology, Melbourne, pp. 249-336.

Mound, L.A. (1997) Biological Diversity. In: Lewis, T. (ed.) Thrips as Crop Pests. CAB International, Wallingford, UK, pp. 197-215.

Mound, L.A. (1998) Another immigrant thrips species in Australia. Victorian Entomologist, 28, 72-73.

Mound, L.A. (1999a) Thysanoptera from Lord Howe Island. Australian Entomologist, 25, 113-120.

Mound, L.A. (1999b) Saltitorial leaf-feeding Thysanoptera (Thripidae, Dendrothripinae) in Australia and New Caledonia, with newly recorded pests of ferns, figs, and mulberries. Australian Journal of Entomology, 38, 257-273.

Mound, L.A. (2000) The aquatic thrips Organothrips indicus Bhatti (Thysanoptera: Thripidae) in Queensland, and a new species, O. wrighti, from tropical Australia. Australian Journal of Entomology, 39, 10-14.

Mound, L.A. (2002a) Research profile. Australian National Insect Collection News, 17, 11-13.

Mound, L.A. (2002b) Thrips and their host plants: new Australian records (Thysanoptera, Terebrantia) Australian Entomologist, 29, 49-60.

Mound, L.A. (2002c) Thysanoptera biodiversity in the neotropics. Revista Biologia Tropical, 50, 477-484.

Mound, L.A. (2002d) Zemiathrips; a new genus of fungus-feeding phlaeothripine Thysanoptera in Australian leaf-litter. Australian Journal of Entomology, 41, 209-215.

Mound, L.A. (2004a) Australian biodiversity-biological diversity and a diversity of studies. Australian Journal of Entomology, 43, 248-257.

Mound, L.A. (2004b) Australian long-tail gall thrips (Thysanoptera, Phlaeothripinae, Leeuweninii), with comments on related Old World taxa. Australian Journal of Entomology, 43, 36-45.

Mound, L.A. (2005a) Florida Pioneer Wilmon Newell: The past, present, and future of insect pest control. Florida Entomologist, 88, 241-243.

Mound, L.A. (2005b) Thysanoptera: diversity and interactions. Annual Review of Entomology, 50, 247-269.

Mound, L.A. (2006) Vicariance and dispersal-trans-Tasman faunal relationships among Thysanoptera (Insecta), with a second species of Lomatothrips from Podocarpus. Papers and Proceedings of the Royal Society of Tasmania, 140, 11-15.

Mound, L.A. (2007) New Australian spore-feeding Thysanoptera (Phlaeothripidae-Idolothripinae). Zootaxa, 1604, 53-68.

Mound, L.A. (2008a) Identification and host associations of some Thysanoptera Phlaeothripinae described from Australia pre1930. Zootaxa, 1714, 41-60.

Mound, L.A. (2008b) Thysanoptera (Thrips) of the World. Online database, available from http://www.ento-csiro.au/ thysanoptera/worldthrips.html (last update: 17 June 2008).

Mound, L.A. (2009a) New taxa and new records of Australian Panchaetothripinae (Thysanoptera, Thripidae). Zootaxa, 2292, 25-33.

Mound, L.A. (2009b) World Thysanoptera, Online database, available from http://anic.ento-csiro.au/thrips/ (updated 30 December 2010).

Mound, L.A. (2009c) A new genus and species of Scirtothrips genus-group (Thysanoptera: Thripidae) from Kenya, intercepted by Australian quarantine, Zootaxa, 2210, 65-68.

Mound, L.A. (2010a) A second Scirtothrips species with a hind-femoral comb in males (Thysanoptera, Thripidae). Zootaxa, 2643, 66-68.

Mound, L.A. (2010b) Species of the genus Thrips (Thysanoptera, Thripidae) from the Afro-tropical Region. Zootaxa, 2423, 124.

Mound, L.A. (2011) Species recognition in the genus Scolothrips (Thysanoptera, Thripidae), predators of leaf-feeding mites. Zootaxa, 2797, 45-53.

Mound, L.A. \& Azidah, A.A. (2009) Species of the genus Thrips (Thysanoptera) from Peninsular Malaysia, with a checklist of recorded Thripidae. Zootaxa, 2023, 55-68.

Mound, L.A. \& Crespi, B.J. (1992) The complex of phlaeothripine thrips (Insecta, Thysanoptera) in woody stem galls of Casuarina in Australia. Journal of Natural History, 26, 395-406.

Mound, L.A. \& Crespi, B.J. (1995) Biosystematics of two new gall-inducing thrips with soldiers (Insecta: Thysanoptera) from Acacia trees in Australia. Journal of Natural History, 29, 147-157.

Mound, L.A. \& Gauld, I.D. (1982) Homoplasy and the delineation of the holophyletic genera in some insect groups. Systematic Entomology, 7, 73-86.

Mound, L.A. \& Halsey, S.H. (1978) Whitefly of the World: A Systematic Catalogue of the Aleyrodidae (Homoptera) with Host Plant and Natural Enemy Data. British Museum (Natural History) and John Wiley \& Sons, New York.

Mound, L.A. \& Kibby, G. (1998) Thysanoptera: An Identification Guide, $2^{\text {nd }}$ ed. CAB International, Wallingford, U.K.

Mound, L.A. \& Houston, K.J. (1987) An annotated checklist of Thysanoptera of Australia. Occasional Papers on Systematic Entomology, 4, 1-28.

Mound, L.A. \& Isaza, J.C. (1994) Trips comunes en la Sabana de Bogota. Asocolflores 38, 55-59.

Mound, L.A. \& Marullo, R. (1993) The Erythrothrips complex of tropical Aeolothripidae (Thysanoptera) with a new Australian genus and a new South African species, Entomologica Scandinavica, 24, 285-291.

Mound, L.A. \& Marullo, R. (1994) New thrips on Mother-in-Law's Tongue. Entomologist's Monthly Magazine, $130,95-98$. 
Mound, L.A. \& Marullo, R. (1996) The thrips of Central and South America: An introduction. Memoirs on Entomology, International, 6, 1-488.

Mound, L.A. \& Marullo, R. (1997) The Hyidiothrips genus-group from tropical leaf-litter (Thysanoptera; Phlaeothripidae), with two new species of the Old-World genus Crinitothrips. Tropical Zoology, 10, 191-202.

Mound, L.A. \& Marullo, R. (1998) Biology and identification of Aeolothripidae (Thysanoptera) in Australia. Invertebrate Taxonomy, 12, 929-950.

Mound, L.A. \& Masumoto, M. (2004) Trichromothrips veversae sp. n. (Insecta, Thysanoptera), and the botanical significance of insects host-specific to Austral bracken fern (Pteridium esculentum). Proceedings of the Linnean Society of NSW, 125, $67-71$.

Mound, L.A. \& Masumoto, M. (2005) The genus Thrips (Thysanoptera, Thripidae) in Australia, New Caledonia and New Zealand. Zootaxa, 1020, 1-64.

Mound, L.A. \& Masumoto, M. (2009) Australian thrips of the Anaphothrips genus-group (Thysanoptera), with three new genera and thirty-three new species. Zootaxa, 2042, 1-76.

Mound, L.A. \& Minaei, K. (2006) New fungus-feeding thrips (Thysanoptera-Phlaeothripinae) from tropical Australia. Zootaxa, 1150, 1-17.

Mound, L.A. \& Minaei, K. (2007) Australian insects of the Haplothrips lineage (Thysanoptera-Phlaeothripinae). Journal of Natural History, 41, 2919-2978.

Mound, L.A. \& Monteiro, R.C. (1998) A review of the genus Heliothrips (Thysanoptera; Thripidae), with a new sister-species of the Greenhouse Thrips from south eastern Brazil. Journal of the New York Entomological Society, 105, 154-160.

Mound, L.A. \& Moritz, G. (2000) Corroboreethrips; a new genus of minute apterous thrips (Insecta, Thysanoptera, Phlaeothripinae) from the bark of Australian Acacia trees. Invertebrate Taxonomy, 14, 709-716.

Mound, L.A. \& Morris, D.C. (1999) Carcinothrips: a new genus of Acacia phyllode-glueing thrips with grossly enlarged forelegs (Thysanoptera: Phlaeothripidae). Australian Journal of Entomology, 38, 10-14.

Mound, L.A. \& Morris, D.C. (2000) Inquilines or kleptoparasites? New phlaeothripine Thysanoptera (Insecta) associated with domicile-building thrips on Acacia trees. Australian Journal of Entomology, 39, 130-137.

Mound, L.A. \& Morris, D.C. (2001) Domicile constructing phlaeothripine Thysanoptera from Acacia phyllodes in Australia: Dunatothrips Moulton and Sartrithrips gen. n., with a key to associated genera. Systematic Entomology, 26, 401-419.

Mound, L.A. \& Morris, D.C. (2007a) The insect order Thysanoptera: classification versus systematics. In: Zhang, Z. -Q., \& Shear, W.A. (Eds) Linnaeus Tercentenary: Progress in Invertebrate Taxonomy. Zootaxa, 1668, 395-41.

Mound, L.A. \& Morris, D.C. (2007b) A new thrips pest of Myoporum cultivars in California, in a new genus of leaf-galling Australian Phlaeothripidae (Thysanoptera). Zootaxa, 1495, 35-45.

Mound, L.A. \& Ng, Y.F. (2009) An illustrated key to the genera of Thripinae (Thysanoptera) from South East Asia. Zootaxa, $2265,27-47$.

Mound, L.A. \& Nickle, D. (2009) The Old-World genus Ceratothripoides (Thysanoptera: Thripidae) with a new genus for related New-World species. Zootaxa, 2230, 57-63.

Mound, L.A. \& O'Neill, K. (1972) Neotropical fungus-feeding Thysanoptera of the genus Sedulothrips (Phlaeothripinae). Florida Entomologist, 55, 251-257.

Mound, L.A. \& O'Neill, K. (1974) Taxonomy of the Merothripidae, with ecological and phylogenetic considerations (Thysanoptera). Journal of Natural History, 8, 481-509.

Mound, L.A. \& Palmer, J.M. (1972) Grass-flower infesting thrips of the genus Chirothrips Haliday in Australia. Journal of the Australian Entomological Society, 11, 332-339.

Mound, L.A. \& Palmer, J.M. (1981a) Phylogenetic relationships between some genera of Thripidae (Thysanoptera). Entomologica Scadinavica, 15, 153-170.

Mound, L.A. \& Palmer, J.M. (1981b) Identification, distribution and host-plants of the pest species of Scirtothrips (Thysanoptera: Thripidae). Bulletin of Entomological Research, 71, 467-479.

Mound, L.A. \& Palmer, J.M. (1982) Thrips rufa Haliday, 1836 (Insecta, Thysanoptera, Thripidae): proposed ruling that this is a nomenclaturally valid name for the type species of Aptinothrips Haliday, 1836. Bulletin of Zoological Nomenclature, 39 , 36-39.

Mound, L.A. \& Palmer, J.M. (1983a) The generic and tribal classification of spore-feeding Thysanoptera (Phlaeothripidae: Idolothripinae). Bulletin of the British Museum (Natural History). Entomology, 46, 1-174.

Mound, L.A. \& Palmer, J.M. (1983b) Spore-feeding Thysanoptera of the genus Anactinothrips with a new subsocial species from Panama. Journal of Natural History, 17, 789-797.

Mound, L.A. \& Palmer, J.M. (1986) Patterns of speciation in Neotropical spore-feeding thrips of the genus Zeugmatothrips. Amazonia, 9, 581-594.

Mound, L.A. \& Palmer, J.M. (1992) Thrips of Panama: a biological catalogue and bibliography (Thysanoptera). In: Quintero, D. \& Aiello, A. (eds.) Insects of Panama and Mesoamerica. Selected Studies. Oxford Science Publications, pp. 321-338.

Mound, L.A. \& Pereyra, V. (2008) Liothrips tractabilis sp.n. (Thysanoptera, Phlaeothripinae) from Argentina, a potential biocontrol agent of weedy Campuloclinum (Asteraceae) in South Africa. Neotropical Entomology, 37, 63-67.

Mound, L.A. \& Postle, A. (2004) Panchaetothrips timonii sp.n. (Thysanoptera, Thripidae); first Australian record of this Old World tropical genus. Australian Journal of Entomology, 43, 133-137.

Mound, L.A. \& Reynaud, P. (2005) Franklinothrips; a pantropical Thysanoptera genus of ant-mimicking obligate predators 
(Aeolothripidae). Zootaxa, 864, 1-16.

Mound, L.A. \& Terry, I. (2001) Thrips pollination of the central Australian cycad, Macrozamia macdonnelli, by a new species of basal clade thrips (Thysanoptera). International Journal of Plant Sciences, 162, 147-154.

Mound, L.A. \& Stiller, M. (2011) Species of the genus Scirtothrips from Africa (Thysanoptera, Thripidae). Zootaxa, 2786, 5161.

Mound, L.A. \& Teulon, D.A.J. (1995) Thrips as phytophagous opportunists. In: Parker, B.L., Skinner, M, \& Lewis, T. (eds). Thrips Biology and Management. Plenum Publishing Corporation, New York, pp. 3-20.

Mound, L.A. \& Tree, D.J. (2007) Oriental and Pacific Thripidae (Thysanoptera) new to Australia, with a new species of Pseudodendrothrips Schmutz. Australian Entomologist, 34, 7-14.

Mound, L.A. \& Tree, D.J. (2009) Identification and host associations of Australian Sericothripinae (Thysanoptera, Thripidae). Zootaxa, 1983, 1-22.

Mound, L.A. \& Walker, A.K. (1982a) Evolutionary significance and generic classification of the Williamsiellina (Thysanoptera: Phlaeothripidae). Systematic Entomology, 7, 347-355.

Mound, L.A. \& Walker, A.K. (1982b) Antennal aberration in Thysanoptera. Entomologist's Monthly Magazine, 118, $175-176$.

Mound, L.A., \& Walker, A.K. (1982c) Terebrantia (Insecta: Thysanoptera). Fauna of New Zealand, 1, 1-113.

Mound, L.A. \& Walker, A.K. (1982d) Faunal relationships between Australia and New Zealand as indicated by Cartomothrips species (Thysanoptera: Phlaeothripidae). Journal of Natural History, 16, 305-313.

Mound, L.A. \& Walker, A.K. (1986) Tubulifera (Insecta: Thysanoptera). Fauna of New Zealand, 10, 1-140.

Mound, L.A. \& Walker, A.K. (1987) Thysanoptera as tropical tramps: new records from New Zealand and The Pacific. New Zealand Entomologist, 9, 70-85.

Mound, L.A. \& Wang, C.-L. (2000) The genus Anascirtothrips (Thysanoptera: Thripidae), from leaves of Ficus trees in India, Taiwan and Australia. Chinese Journal of Entomology, 20, 327-333.

Mound, L.A. \& Wells, A. (2007) A new genus for an Australian thrips (Thysanoptera, Phlaeothripinae) associated with a waxy eriococcid (Hemiptera, Coccoidea). Zootaxa, 1645, 57-61.

Mound, L.A. \& Williams, G. (2003) Host-plant Disjunction in a New Species of Neohoodiella (Insecta, Thysanoptera, Phlaeothripinae), with Notes on Leaf-Frequenting Thrips in NSW Subtropical Rainforest. Proceedings of the Linnean Society of NSW, 124, 17-28.

Mound, L.A. \& Zapater, M.C. (2003) South American Haplothrips species (Thysanoptera, Phlaeothripidae), with a new species of biological control interest to Australia against weedy Heliotropium amplexicaule (Boraginaceae). Neotropical Entomology, 32, 437-442.

Mound, L.A., Goodwin, S. \& Steiner, M.Y. (1996) Neohydatothrips pseudoannulipes Johansen (Thysanoptera: Thripidae), a pest thrips on African marigolds new to Australia. Australian Journal of Entomology, 35, 201-202.

Mound, L.A., Heming, B.S. \& Palmer, J.M. (1980) Phylogenetic relationships between the families of recent Thysanoptera. Zoological Journal of the Linnean Society of London, 69, 111-141.

Mound, L.A., Crespi, B.J. \& Kranz, B. (1996) Gall-inducing Thysanoptera (Phlaeothripidae) on Acacia phyllodes in Australia: host-plant relations and keys to genera and species. Invertebrate Taxonomy, 10, 1171-1198.

Mound, L.A., Crespi, B.J. \& Tucker, A. (1998) Polymorphism and kleptoparasitism in thrips (Thysanoptera: Phlaeothripidae) from woody galls on Casuarina trees. Australian Journal of Entomology, 37, 8-16.

Mound, L.A., Martin, J.H. \& Polaszek, A. (1994) The insect fauna of Selaginella (Pteridophyta: Lycopsida), with descriptions of three new species. Journal of Natural History, 28, 1403-1415.

Mound, L.A., Marullo, R. \& Trueman, J.W.H. (2001) The greenhouse thrips, Heliothrips haemorrhoidalis, and its generic relationships within the sub-family Panchaetothripinae (Thysanoptera; Thripidae). Journal of Insect Systematics and Evolution, 32, 1-12.

Mound, L.A., Nakahara, S. \& Day, M.D. (2005) Frankliniella lantanae sp.n. (Thysanoptera); a polymorphic alien thripid damaging Lantana leaves in Australia. Australian Journal of Entomology, 44, 279-283.

Mound, L.A., Retana, A.P. \& du Heaume G.J. (1994) Claves ilustradas para las familias y los géneros de Terebrantia (Insecta: Thysanoptera) de Costa Rica Y Panamá. Revista Biologia Tropical, 41, 709-727.

Mound, L.A., Tree, D.J. \& Goldarazana, A. (2010a) A new species of predatory Scolothrips (Thysanoptera, Thripidae) feeding on Raoiella mites (Tenuipalpidae) in Australia. Zootaxa, 2620, 63-68.

Mound, L.A., Wheeler, G. \& Williams, D.A. (2010b) Resolving cryptic species with morphology and DNA; thrips as a potential biocontrol agent of Brazilian pepper tree, with a new species and overview of Pseudophilothrips (Thysanoptera). Zootaxa, 2432, 59-68.

Mound, L.A., Zhang, H.-R. \& Bei, Y.-W. (2011) Caliothrips tongi sp.n. (Thysanoptera, Thripidae) from China, and a dubious record of North American Bean Thrips. Zootaxa, 2736, 57-62.

Ng, Y.F., Eow, L.X. \& Mound, L.A. (2010) A new species of genus Thrips (Thysanoptera, Thripinae) from flowers in Peninsular Malaysia. Zootaxa, 2638, 65-68.

Palmer, J.M. \& Mound, L.A. (1978) Nine genera of fungus-feeding Phlaeothripidae (Thysanoptera) from the Oriental Region. Bulletin of the British Museum (Natural History). Entomology, 37, 153-215.

Palmer, J.M. \& Mound, L.A. (1983) The Scirtothrips species of Australia and New Zealand (Thysanoptera: Thripidae). Journal of Natural History, 17, 507-518.

Palmer, J.M. \& Mound, L.A. (1985) New World Thripidae (Thysanoptera) with nine-segmented antennae. Zoological Journal 
of the Linnean Society, 84, 181-194.

Palmer, J.M., Mound, L.A. \& du Heaume, G.J. (1989) Chapter 2. Thysanoptera. In: Betts, C.R. (Ed.), Guides to Insects of Importance to Man. CAB International Institute of Entomology and British Museum (Natural History), London.

Pereyra, V. \& Mound, L.A. (2009) Phylogenetic relationships within the genus Cranothrips (Thysanoptera, Melanthripidae) with consideration of host associations and disjunct distributions within the family. Systematic Entomology, 34, $151-161$.

Pereyra, V. \& Mound, L.A. (2010) Phylogenetic relationships with the genus Desmothrips (Thysanoptera, Aeolothripidae), an Australian genus of facultative flower-living predators. Systematic Entomology, 35, 306-317.

Perring, T.M. (2001) The Bemisia tabaci species complex. Crop Protection, 20, 725-737.

Pinent, S.M.J., Romanowski, H.P., Reddaelli, L.R. \& Mound, L.A. (2003) Thrips species (Thysanoptera) collected at Parque Estadual de Itapua, Viamao, RS, Brazil. Neotropical Entomology, 32, 619-623.

Pitkin, B.R. \& Mound, L.A. (1973) A catalogue of West African Thysanoptera. Bulletin del'Institute Fondemental de l'Afrique Noire, 35, 407-449.

Priesner, H. (1949) Genera Thysanopterorum. Bulletin de la Societe Fouad I' d'Entomologie, 33, 34-57.

Priesner, H. (1965) A monograph of the Thysanoptera of the Egyptian deserts. Publications de l'Institut Desert d'Egypte, 13, $1-549$.

Retana, A. \& Mound, L.A. (2005) Character state variation in a new genus and species of Thripidae (Insecta: Thysanoptera) associated with Chamaedorea (Arecaceae) inflorescences in Central America. Brenesia, 63-64, 121-126.

Ripa, R., Funderburk, J., Rodriguez, F., Espinoza, F. \& Mound, L. (2009) Population abundance of Frankliniella occidentalis (Thysanoptera: Thripidae) and natural enemies on plant hosts in Central Chile. Environmental Entomology, 38, $333-344$.

Rugman-Jones, P.F., Hoddle, M.S., Mound, L.A. \& Stouthamer, R. (2006) A molecular identification key for pest species of Scirtothrips (Thysanoptera: Thripidae). Journal of Economic Entomology, 99, 1813-1819.

Rugman-Jones, P.F., Hoddle, M.S. \& Stouthamer, R. (2010) Nuclear-mitochondrial barcoding exposes the global pest Western flower thrips (Thysanoptera: Thripidae) as two sympatric cryptic species in its native California. Journal of Economic Entomology, 103, 877-886.

Stannard, L.J. (1957) The phylogeny and classification of the North American genera of the suborder Tubulifera (Thysanoptera). Illinois Biological Monographs, 25, 1-200.

Stannard, L.J. (1968) The thrips, or Thysanoptera of Illinois. Bulletin of the Illinois State Natural History Survey, $29,215-552$.

Tillekaratne, K., Mound, L., zur Strassen, R. \& Edirisinghe, J.P. (2007) List of thrips (Thysanoptera) recorded from Sri Lanka. Journal of the National Science Foundation of Sri Lanka, 35, 197-205.

Tschuh, G., Lindemann, P., Rettig, W., Mound, L.A. \& Moritz, G. (2006) Designer-Lipide auf dem Wachs einer Schildlaus (Coccoidea, Eriococcidae). Mitteilungen der Deutschen Gesellschaft für Allgemeine und Angewandte Entomologie, 15, $143-146$.

Tree, D.J. \& Mound, L.A. (2009) Gall-induction by an Australian insect of the family Thripidae (Thysanoptera: Terebrantia). Journal of Natural History, 43, 1147-1158.

Tyagi, K., Kumar, V. \& Mound, L.A. (2008) Sexual dimorphism among Thysanoptera Terebrantia, with a new species from Malaysia and remarkable species from India in Aeolothripidae and Thripidae. Insect Systematics and Evolution, 39, 155170.

Wang, C.-L. \& Mound, L.A. (1996) Pictorial key to the pest species of thrips in Taiwan [in Chinese] Journal of Agricultural Research of China, 44, 344-356.

Wills, T.E., Chapman, T.W., Mound, L.A., Kranz, B.D. \& Schwarz, M.P. (2004) Natural history and description of Oncothrips kinchega, a new species of gall-inducing thrips with soldiers (Thysanoptera: Phlaeothripidae). Australian Journal of Entomology, 43, 169-176.

Xie Y.-H., Zhang, H.-R. \& Mound, L.A. (2010) A new species from southwestern China of the holarctic genus Odontothrips (Thysanoptera: Thripidae). Zootaxa, 2729, 53-57.

Zerega, N.J.C., Mound, L.A. \& Weiblen, G.D. (2004) Pollination in the New Guinea endemic Antiaropsis decipiens (Moraceae) is mediated by a new species of thrips, Thrips antiaropsidis sp. nov. (Thysanoptera: Thripidae). International Journal of Plant Sciences, 165, 1017-1026.

Zhang, H.-R., Mound, L.A. \& Xie, Y.-H. (2010) A new genus and species from southwestern China in the Frankliniella genusgroup (Thysanoptera: Thripidae). Zootaxa, 2729, 65-68.

zur Strassen, R. (1960) Catalogue of the known species of South African Thysanoptera. Journal of the Entomological Society of South Africa, 23, 321-367. 